\title{
1 Amblyomma mixtum free-living stages: Summer and winter use, preference, 2 and niche width in an agroecosystem (Yopal, Casanare, Colombia)

4 Elkin Forero-Becerra ${ }^{1 *}$, Alberto Acosta ${ }^{2}$, Efraín Benavides ${ }^{3}$, and Marylin Hidalgo 4

5 1Postdoctoral fellow - Colciencias call 784/2017, Departament of Microbiology, Faculty of Sciences, Pontificia Universidad 6 Javeriana, Bogotá Campus, Bogotá, D.C., Colombia.

7 2UNESIS (Unidad de Ecología y Sistemática), Departament de Biology, Faculty of Sciences, Pontificia Universidad Javeriana, 8 Bogotá Campus, Bogotá, D.C., Colombia.

$9 \quad{ }^{3}$ Grupo de Investigación Epidemiología y Salud Pública, Facultad de Ciencias Agropecuarias, Universidad de La Salle, Bogotá, 10 Colombia.

$11{ }^{4}$ Laboratorio de Bacteriología Especial, Departament of Microbiology, Faculty of Sciences, Pontificia Universidad Javeriana, 12 Bogotá Campus, Bogotá, D.C., Colombia.

\section{${ }^{*}$ Corresponding author}

15 E-mail: egforerob@unal.edu.co. (EF-B)

Running Head: Amblyomma mixtum habitat use and preference.

Studying a species' tolerance to an ecosystem's environmental conditions and its selection

21 of available resources is relevant in ecological and evolutionary terms. Moreover, formulation of

22 effective control strategies implicitly includes the study of habitat use and preference and niche width

23 in anthropogenically transformed natural landscapes. Here, we evaluated whether the use, habitat preference, and niche range of the Amblyomma mixtum tick changed between stages, habitats, and

25 seasons (summer-winter 2019) on a farm in Yopal (Casanare, Colombia). To this end, the presence 26 and relative abundance of larvae, nymphs, and free-living adults was quantified in four different

27 habitats according to the type of vegetation cover (Riparian Forest, Cocoa Crop, King Grass Crop, 28 and Star Grass Paddock). Habitat availability was calculated, environmental variables were analyzed, 
29 and various indices of habitat use and preference and niche width were calculated. A. mixtum's

30 habitat use and preference and niche width changed between stages, habitat types, and time of the

31 year. The total abundance of $A$. mixtum was an order of magnitude greater in summer than winter.

32 Nymphs and larvae dominated it in the summer and adults in the winter. In summer, all the stages

33 used the four habitats. In winter, the larvae did not use two habitats (Riparian Forest and Cocoa

34 Crop); nymphs did not use the cocoa crop. A. mixtum adults used all the habitats in both seasons. In

35 summer, the nymphs and larvae preferred three of the four habitats (King Grass Crop, Star Grass

36 Paddock, and Cocoa Crops), while adults preferred the King Grass Crop. In winter, the nymphs and

37 larvae preferred the King Grass Crop and Star Grass Paddock, while the adults preferred the King

38 Grass Crop. The value of the niche width index was high for larvae, nymphs, and adults in summer,

39 while it was high only for adults in winter. A. mixtum is exposed to significant daily, seasonal, and

40 multiannual variations in relative humidity (minimum $30 \%$ ), ambient temperature (minimum $18^{\circ} \mathrm{C}$ ),

41 solar radiation (maximum $800 \mathrm{~W} / \mathrm{m}^{2}$ ), and precipitation (maximum $481 \mathrm{~mm} / \mathrm{month}$ ). Thus, the local $A$.

42 mixtum population could rapidly acclimatize to changing habitats (unstable or temporary) under

43 fluctuating environmental conditions (e.g., King Grass Crop). However, the winter flood season in

44 Yopal could exceed A. mixtum's adaptive capacity during its most vulnerable stages. Mathematically,

45 a low number of female A. mixtum, surviving the most demanding environmental conditions, could

46 sufficiently ensure the population's persistence, which, coupled with the vast host range, could

47 facilitate the ticks stages' dispersal among habitats to complete their life cycle. A. mixtum's population

48 control should be carried out during its season of greater vulnerability (winter), when the population

49 is low, particularly the females.

51 Keywords: Vegetation cover, niche, Amblyomma mixtum, free-living stages, Colombian low tropics.

\section{Introduction}


Animals' habitat use, preference, niche width, and resource selection allows researchers to

56 explain abundance, spatial distribution (occurrence maps for conservation or health planning

57 purposes), and evolutionary processes (cost and benefits of differential habitat use, adaptations,

niche separation, and speciation) of a given organism-species to infer its ecological requirements

59 (animal-habitat relationships) in a changing world, including the effects of human activities (habitat loss) on wildlife's ability to colonize and use specific areas [1-3].

Habitat is defined as the place with all the conditions and resources necessary for survival, development, reproduction, and the establishment of local populations [4]. Habitat is also the spatially limited site where abundance or other population parameters (rate of growth $=\mathrm{R}$ ) differ from those of other localities or contiguous patches, or habitats [5]. For example, in host-parasite relationships, as in ticks, the host is both the space and habitat that offers the resource (e.g., blood to the parasite). Different host types will define the tick's population abundance. However, this does not mean that all the available hosts in the habitat will be used. Resources are defined by [6] as a discrete unit (attributes or environmental variables), such as forest, grassland, or crop categories, within the vegetation cover types that an animal may encounter, use, and discriminate. Thus, an animal will instinctively determine, based on cost-benefit, which category of any particular resource should be used. A used resource unit is the one that has received some investment by an animal, including time-energy expended, distance traveled, or residence time in the unit-habitat [3]. available resource unit, or one spatially limited by the researcher, is one that can potentially be encountered by an animal [3], depending on the presence or absence of limiting factors, such as physical and biological (parasitism, predation, and competition) in time and space, that could prevent

77 the establishment, survival, development, or reproduction of any given organism [2]. If such an animal 78 is not found, the target resource and the habitat is considered unused. Availability is similarly defined 79 by the proportional occurrence (area) of discrete levels of a resource; that is, the area covered by 80 different vegetation types or habitats. In resource selection studies, it is important to define availability 81 because it determines the spatial distribution of resources in those habitats against which use is 82 compared [7]. Comparing used to unused resource units, or other used units, to available resource 
83 units allows inferences regarding selection and preference [3]. Habitat preference, on the other hand,

84 is understood as a consequence of habitat selection by a reproductive female, larvae, nymph or adult,

85 or the non-random asymmetric use of any resource(s) by each individual stage in the population, over

86 other possible resources found in other available habitats [5]. Habitat preference must be inferred at

87 the population level. It results from many individuals choosing the same physical or biological

88 resource in a habitat (i.e. refuge), even over the availability of others [2].

However, the asymmetric use of any resource(s) in the habitat depends on the organism's

90 requirements. It also varies in time and space in relation to life cycle stages or a change in resources

$91[3,8]$. Also, it depends on the quality, quantity, and availability of resources in a particular habitat [9].

92 Essentially, an animal's habitat preference is assessed by its relative population abundance in all the

93 habitats it uses, including their resources, according to the availability of comparable habitats (area

94 of potential use with resources an animal can encounter). As stated by some authors $[2,10]$, this

95 implies establishing realistic biological categories depending on the organisms' life history (larvae,

96 nymphs, adults) and the discrete habitats (resources) that the organisms may use (grass, crops,

97 forest), not use, select, and prefer (asymmetric use) at the population level.

98 On the other hand, the concept of niche width refers essentially to the diversity of resources

99 used and conditions needed in a habitat by any organism or group of organisms [11]. In other words,

100 the way a species exists in the habitat using resources (hiding, hunting, moving, and parasitizing) and

101 the habitat conditions (environmental factors, like site quality, temperature, and humidity) in which

102 organisms occur and how such conditions affect it (survival, diapause, death). Thus, species

103 abundance and spatial distribution are attributed to its niche amplitude (both as a proxy) [11]. A niche

104 is one specie's multidimensional space, where a measurement of its dimensions (one or the set of

105 environmental factors) is called niche width, breath, or amplitude [12]. In any habitat, each factor can

106 have a lower or upper limit. Anything below or above those limits will hinder the species from growing

107 or cause its elimination (exceeding its tolerance limits).

108 These limits are the optimum range for species performance, survival, and positive population

109 growth rate. [13] indicated that a factor's range between minimum and maximum values represents

110 the specie's ecological amplitude for that factor. Species with wide niche breadth are highly 
111 adaptable. They can use a broader spectrum of resources, even with limited efficiency, according to 112 scarcity or availability of those resources in the habitat. They can adjust easily (through 113 morphological, physiological, and behavioral traits) to changes in the environment. These species

114 could potentially live in a broad range of temperature or humidity conditions, and they can also attain 115 higher population abundances and occupy several different habitats (resource possibilities).

116 These species are referred to as generalist species and include several Amblyomma tick 117 species. Specialist species have a narrow niche breadth [14]. Habitat quality determines a species' 118 performance (presence, abundance, fitness, and growth rate) related to its niche breadth. In turn, the 119 species' performance (high or low abundance) could indicate the habitat's attributes (good or bad 120 [13]). Although it is difficult to describe and find any specie's ecological niche (infinite niche 121 dimensions), few significant variables and the species response to each of them (survival, 122 abundance) may be sufficient to measure its established niche and infer its niche width [11].

123 Therefore, a specie's selection of one or more habitats throughout its life cycle (stages) is 124 essential to the population's preservation and persistence. Biotic and abiotic factors and habitat 125 resources affect survival, reproduction, population growth rate, and spatial distribution at different 126 time and space scales, evolutionary and/or ecological. Depending on the species' niche, individuals 127 actively seek out and select habitats that provide an adequate range of conditions and resources [15]. 128 However, natural habitats are constantly changing, and so are the species. Through evolutionary 129 processes, they can adapt their morphology, physiology, and behavior to use new habitats, even 130 managing to expand their fundamental ecological niche to unstable and dynamic habitats [16].

131 Human activities, for instance, benefit synanthropic species' spatial distribution and 132 abundance [17] by expanding their established niche [18], particularly in agroecosystems [19]. The 133 favored species (like some ticks) increase their dispersion capacity, colonizing different habitats, and 134 decreasing their extinction probability [20]. Forest degradation and fragmentation, for example, have 135 prompted the occurrence of Amblyomma aureolatum in urban areas of the city of São Paulo (Brazil) $136[21,22]$.

137 Several field studies have evaluated Amblyomma ticks' seasonal population dynamics and 138 abundance (see [23-29]). However, few have approached the use of resources in the habitat or the 
139 inference of their niche range on a local scale. That is, A. mixtum's preference for various habitats in

140 a single agroecosystem, the role that the domestic and wild host community would play there, the

141 competition for resources from those habitats with other ticks, and the associated dynamics of

142 rickettsial infection in local animals and humans are not known. Some examples of research on

143 ixodids of vector-pathogen-host relationships are Ixodes scapularis [30]; Amblyomma fuscum [31];

144 Amblyomma americanum [32]; Amblyomma aureolatum and Amblyomma ovale [33]; Amblyomma

145 triste [34]; Ixodes ricinus [35]; Ixodes pacificus [36]; Amblyomma tuberculatum [37]; Rhipicephalus

146 microplus [38], and Amblyomma maculatum [39].

147 Although some factors that could affect Amblyomma mixtum's habitat use have been studied

148 at the local [40] or laboratory level [41], or modeled on a regional [42] or continental scale [43], there

149 is still a lack of empirical information that evaluates and integrates aspects of this tick's use, habitat

150 preference, and niche range in an agricultural system and whether the non-parasitic stages and

151 population respond differently over time (seasonality). Likewise, there are no studies in Colombia that

152 clearly indicate A. mixtum's limit of altitudinal distribution in the Eastern Cordillera or explanations

153 based on empirical data of its absence in the Bogota savannah. There is a trend towards studying

154 the tick's eco-epidemiology, particularly the limits of their geographic distribution, using mathematical

155 modelings of their niche based on records of local presence and seasonal abundance [44]. However,

156 the absence of observations cannot be interpreted as the specie's non-existence in the site [45].

157 These models are used to obtain mechanistic explanations of vectors and pathogens'

158 dynamics or predict transmission risks in space and time. However, detailed empirical information is

159 needed to add biological realism levels to understand that not all ticks and their hosts behave the

160 same way in all environments [46]. Therefore, obtaining empirical information on a tick species' life

161 history, its tolerance to extreme abiotic variables values, and its interaction with abiotic factors is

162 crucial for decision making about the management of the vector and its impact on public health.

163 Ticks of the Amblyomma genus have been recognized as vectors of rickettsial agents in a

164 number of countries; thus, the importance of their study [47]. In Colombia, some species, particularly

165 those included in the Amblyomma cajennense species complex (see [48]), have been reported

166 infected with Rickettsia rickettsii. Such is the case of Amblyomma patinoi (Villeta, Cundinamarca [49]), 
167 A. cajennense sensu lato (La Sierra and Rosas, Cauca, [50]), and Amblyomma mixtum in several 168 regions, including Yopal (Casanare [51]).

169 According to a recent epidemiological study in the Matepantano farm in Yopal, Casanare 170 (Hidalgo, et al., unpublished information), there is a high proportion of the human population (92\%, 171 77/84) with antibody titers to Rickettsia spp. due to their exposure to ticks. Considering the scarce 172 information existing between non-parasitic $A$. mixtum's stages and its relationship with resources and 173 habitat conditions, we investigated the population's use and preference of four different habitats and 174 their niche width. We compared the summer (February) and winter (August) to see if, as had been 175 suggested [3], the seasonal variation (precipitation, humidity, and temperature) could altered the use 176 and preference of the habitats and the niche width (intraspecific variation).

\section{Materials and methods}

\section{Habitat selection and sampling details}

The work was carried out within what we have called Matepantano farm, an area surrounding part of the main installations of the Hacienda Matepantano (Fig 1), a private-owned land where

182 academic agricultural spaces and activities occur (Vereda Matepantano, Yopal, Casanare,

183 Colombia). Non-protected species were sampled. The field collections were possible thanks to the 184 permissions of the Ministry of the Environment of Colombia (001-2018). The farm is located at an 185 altitude between $256-270$ m.a.s.I. It is delimited by gallery forest corridors, which are home to wildlife. 186 Initially, hundreds of successive aerial images, taken with a digital camera mounted on a Phantom 4 187 Advanced DJI drone from an altitude of $150 \mathrm{~m}$ (S1 Appendix), were used to create an orthomosaic 188 of the study area (domain) in ArcGIS Desktop® (Esri, Redlands, CA, USA).

Fig. 1. Aerial view of the study area at the Matepantano farm. Red lines encircled areas of the selected habitats. 
194 crops, and pastures, to see their effect on A. mixtum's use of resources. The different habitats were

195 defined and delimited on the orthomosaic according to the type of vegetation and the different patches

196 of vegetation within each habitat (Fig 2). Then, ArcGIS was used to calculate the total area of the

197 Matepantano farm (3'203.786.9 $\left.\mathrm{m}^{2}\right)$ and the area of each of the four selected habitats. Only those

198 areas (discrete patches or paddocks) of habitat where tick sampling was conducted were considered

199 (previously confirmed presence of $A$. mixtum in pre-samples).

Fig. 2. Map of the study area at the Matepantano farm and the four selected habitats. The study area is about $3,2 \mathrm{~km}^{2}$ representing a 6\% of the total area of Matepantano estate. Conventions: 1- Star Grass paddocks (1'955,090 m²); 2- King Grass crop (22,416 m²); 3- Cocoa crop (81,341 $\left.\mathrm{m}^{2}\right)$; 4- Riparian forest (646,099 $\left.\mathrm{m}^{2}\right)$; 5- Main buildings area (112,833 $\left.\mathrm{m}^{2}\right)$; 6 - Other area $\left(386,007 \mathrm{~m}^{2}\right) ; 7-\mathrm{CO}_{2}$ traps; 8- Dragging by cloth transects; 9- Regional localization of the Matepantano farm. Note: All $\mathrm{CO}_{2}$ traps and dragging by cloths transects with GPS data for both seasons, summer and winter, are represented.

The areas finally selected were the following: riparian forest, $450.552 \mathrm{~m}^{2}$ of a total of 646.099.0 $\mathrm{m}^{2}$; cocoa crop (Theobroma cacao), $59.940 \mathrm{~m}^{2}$ of a total of $81.341 .3 \mathrm{~m}^{2}$; Star Grass paddock, $54.968 \mathrm{~m}^{2}$ of a total of 1'955.090.4 m²; and King Grass crop, $13.245 \mathrm{~m}^{2}$ of a total of 22.416 .3 $\mathrm{m}^{2}$. For this study, these four areas were called "available area"; that is, areas with potential to be used by the A. mixtum tick population. This available area is essential in determining the observed

212 use in each habitat (presence and abundance of ticks) and defining habitat preference and niche 213 width (indices applied). All four habitats were equally represented in the habitat availability area,

214 except for the 'Star Grass paddock,' which we did not want to over-represent in the habitat availability, 215 given its higher proportion in the domain area (Fig 2).

216 The mathematical calculations (indices) used the same values for summer and winter in the

217 four available areas, given that the same points were sampled in time. Within the Matepantano farm, 218 some areas were not sampled, such as buildings for academic, recreational, food, and residential 219 activities and some discrete patches of the four habitats $\left(386.007 .0 \mathrm{~m}^{2}\right)$ (Fig 2). A sampling of free220 living ticks within each habitat was performed from February $8^{\text {th }}$ to $12^{\text {th }}, 2019$, during the summer 221 season (November-March) and from August $16^{\text {th }}$ to $19^{\text {th }}, 2019$, during the winter season (April222 October). Seasonality alters the relationship between the tick and the use of the resource-habitat [3]. 
223 Within each habitat category, the $\mathrm{CO}_{2}$ trap and white flannel dragging transect sampling units

224 (grouping all the individuals captured by trap or transect) were located at convenience, following

225 biological criteria (biology and pattern of tick activity and the probability of being a human vector),

226 with replicates for each habitat (where abundance and presence-use response variables were

227 measured). The habitat fragments, patches, and paddocks, chosen and sampled from the

228 photomosaic, favored those within a radius of approximately $500 \mathrm{~m}$ from the buildings of the

229 Matepantano farm, including the places frequently used for work and agropastoral practices (Figs 1

230 and 2). The number of traps and transects were fairly similar between habitats to facilitate comparison

231 of relative abundances. Random sampling was not used for the location of the sampling units (trap

232 or transect) in the vegetation types because, as indicated by other authors [3], this usually results in

233 few or no observations of habitat use.

\section{Generalities of the compared habitats}

Riparian Forest $\left(5.32224^{\circ} \mathrm{N}\right.$ and $\left.72.28696^{\circ} \mathrm{W}\right)$. This habitat was a gallery forest bordered

237 by a permanent creek and dominated by adults and juveniles of the Attalea butyracea (Arecaceae)

238 palm, a closed canopy, and an open understory (Table 1). There was no apparent change in

239 vegetation structure between summer and winter (stable structure), with saturated soil in winter and

240 litter in both seasons. Tick abundance sampling was conducted between 2 and $8 \mathrm{~m}$ into the forest,

241 outside the edge zone.

243 Table 1. Structural characteristics of the four habitat selected where ticks were collected.

\begin{tabular}{|c|c|c|c|c|}
\hline & Riparian forest & Cocoa crop & King Grass crop & Star Grass paddocks \\
\hline $\begin{array}{c}\text { Dominant terrestrial } \\
\text { vegetation }\end{array}$ & $\begin{array}{c}\text { Palm } \\
\text { (Attalea butyracea). } \\
\text { Poor litter with presence } \\
\text { of nuts, tree branches, } \\
\text { litter debris and fungi. }\end{array}$ & $\begin{array}{l}\text { Cocoa, acacia, banana } \\
\text { trees. Acacia leaves } \\
\text { dominates the litter with } \\
\text { fruits and tree branches. }\end{array}$ & $\begin{array}{l}\text { King grass dominates } \\
\text { this area with some } \\
\text { scattered trees and } \\
\text { thorny bushes. There is } \\
\text { no litter. }\end{array}$ & $\begin{array}{l}\text { Star grass (Cynodon } \\
\text { sp.) and kermes oak. } \\
\text { Litter was scarce with } \\
\text { predominance of grass } \\
\text { dry leaves. Soil is } \\
\text { floodable by rains, but }\end{array}$ \\
\hline
\end{tabular}




\begin{tabular}{|c|c|c|c|c|}
\hline & & & & $\begin{array}{l}\text { humidity was found } \\
\text { during a } 24 \mathrm{~h} \text { period. }\end{array}$ \\
\hline $\begin{array}{c}\text { Natural light availability } \\
\text { (\%) }\end{array}$ & 25 & 50 & 100 & 100 \\
\hline $\begin{array}{c}\text { Number of vegetation } \\
\text { strata }\end{array}$ & 4 & 3 & $1-2$ & 2 \\
\hline Litter depth (cm) & $2,9( \pm 1,6)$ & $6,8( \pm 3,5)$ & $8,5( \pm 2,2)$ & $2,8( \pm 2,8)$ \\
\hline $\begin{array}{l}\text { Litter humidity (\%) } \\
\text { in summer }\end{array}$ & $56,4( \pm 6,5)$ & $47,4( \pm 5,1)$ & $62,9( \pm 8,2)$ & $39,9( \pm 6,7)$ \\
\hline Soil dominant fraction & Clay soil with some sand. & $\begin{array}{c}\text { Clay soil (alfisol type). } \\
\text { Arcilloso - tipo alfisol. There } \\
\text { are rocks at deeper digging. } \\
\text { The soil has acidic } \mathrm{pH} .\end{array}$ & $\begin{array}{l}\text { Clay soil with few silt and } \\
\text { fine sand soils. }\end{array}$ & Clay soil. \\
\hline
\end{tabular}

Cocoa Crop $\left(5.32312^{\circ} \mathrm{N}\right.$ and $\left.72.28691^{\circ} \mathrm{W}\right)$. This habitat was a cacao crop (Theobroma

cacao). The farm used the tresbolillo technique to plant the cocoa. This technique entails locating the plants in a triangular shape with a distance of $3.5 \times 3.5 \mathrm{~m}$ between them. The crop was mixed with Acacia trees to provide shade (Table 1), in addition to some banana plants. In summer, the crop soil was dry (cracked), with leaf litter and dehydrated plants caused by a couple of months of drought (december-january). In winter, the soil was saturated, and the vegetation was green. Leaf litter was observed in both summer and winter.

King Grass Crop $\left(5.32482^{\circ} \mathrm{N}\right.$ and $\left.72.28704^{\circ} \mathrm{W}\right)$. This habitat was a King Grass plantation

253 (Pennisetum hybridum). In summer, the grass was dry (yellow) and uncontrolled, sometimes broken, 254 but dense, with a height of between 1 and $2 \mathrm{~m}$ and interspersed with thorny shrubs and very few 255 scattered trees (Table 1). In winter, the same pasture was green (1.8 $\mathrm{m}$ high), and the soil was wet 256 from rainfall. The search for ticks was conditioned by accessibility and the possibility of placing the 257 bases of the $\mathrm{CO}_{2}$ traps among the dense grassland. However, the collection points were distributed 258 broadly over the habitat patches. 
reached a height of $20-40 \mathrm{~cm}$ in the paddocks and had some scattered bushes (Table 1). In summer,

262 the grass in the paddock was dry and yellow. The soil was dry and cracked due to the drought. In

263 winter, the grass was green, and the soil partially flooded a few centimeters $(<10 \mathrm{~cm}$ after rain);

264 however, it percolated quickly from one day to the next.

265 The four habitats' (Riparian Forest, Cocoa Crop, Star Grass Paddock, King Grass Crop)

266 vegetation's structural characteristics (Table 1), such as dominant species, light availability, number

267 of strata, depth of leaf litter above the soil, percentage of leaf litter moisture, and dominant soil fraction,

268 were qualified and quantified (details in S2 Appendix) in the points where ticks were sampled.

To define habitat use or non-use, the habitat preference and relative niche width by $A$. mixtum

272 free-living stages, the relative abundance response variable of individuals in each habitat (presence

273 indicating resource use and tolerance to abiotic conditions in the habitat) were used as a proxy for

274 resource selection in the habitat. Based on previous field experiences, it was decided to capture free-

275 living stages of $A$. mixtum through two techniques, $\mathrm{CO}_{2}$ traps (dry ice) and white flannel dragging

276 transects (see [52-54]).

277 Use of $\mathrm{CO}_{2}$ traps. The details of these traps' construction before their placement are

278 presented in S3 Appendix. According to vegetation cover, the traps were placed in relatively flat sites

279 and areas, which according to locals, were frequented by domestic and wild animals, and considering

280 their proximity to transited areas (corridors) or roads used by campus workers and students. A

281 minimum number of four $\mathrm{CO}_{2}$ traps were placed in each habitat and season (February, August), once

282 per habitat type, and separated by a minimum distance of $5 \mathrm{~m}$. Sampling was conducted between

283 8:00 am and 1:30 pm, and 2:30 and 4:30 pm, or until all dry ice was consumed. The traps were

284 checked every 30 minutes. The ticks caught on the double-faced tape and those nearby, were

285 collected. Twenty-four traps were placed in the summer and 24 in winter. Another seven traps (55

286 traps in total) were used to ensure the "non-use" of particular habitats in some tick free-living stages

287 (S1 and S2 Tables). The captured specimens were collected with entomological tweezers, deposited 
288 in $50 \mathrm{ml}$ centrifuge tubes with $70 \%$ ethanol, and labeled. Later, in the laboratory, the specimens were

289 identified and counted according to genus or species, sex, and stage.

290 White flannel dragging transects. Details of this activity's outputs and the size of the

291 quantified transects are presented in the S3 Appendix. The sampling was done between 8:00 am and

$292 \quad$ 1:30 pm, and between 2:30 and 4:30 pm, covering several habitats in one day. The transects were

293 separated from each other by at least $5 \mathrm{~m}$. A minimum number of four transects per habitat was

294 performed, once in each season of the year. In the riparian forest habitat, flannel trails were performed

295 when possible, following the paths created by the wildlife and tree base or herbaceous creeping

296 vegetation $(<70 \mathrm{~cm})$. The total number of flannel transects was 22 for each time of year, for a total of

29744 in the two seasons (S3 and S4 Tables). Two teams of three researchers simultaneously carried

298 out the sampling, using the two capture techniques in each habitat. Each team initially installed the

299 corresponding $\mathrm{CO}_{2}$ traps in the four habitats. Flannel dragging was carried out in the defined transects

300 between the time intervals of the trap inspections.

\section{Taxonomic identification of specimens}

Stereoscopy was used to identify the morphological characteristics in adults and some

304 characteristics in nymphs. Light microscopy was used to identify certain morphological characteristics

305 in immature individuals (larvae and nymphs) by mounting specimens between lamina and lamella

306 (subsample of the specimens captured in the habitats and seasons). The taxonomic keys of several

307 authors [55] were used for the genus Amblyomma and for the Amblyomma cajennense complex [56-

308 59]. The descriptions made by [48] was used to define the species A. mixtum.

\section{Inference of use, habitat preference, and niche width}

This study assumed that the presence of ticks in a habitat is possible because: 1) ticks use

312 one or more resources (even if we do not know exactly which or what those resources are, given the

313 lack of biological data on the species [3], and 2) ticks tolerate the habitat's environmental conditions

314 where we found them [3]. Therefore, we used a paired used/availability habitat design with four 
315 discrete levels of habitats with different types of vegetation, such as tropical, riparian evergreen forest, 316 tall grass plantation (King Grass), grazing grass (Star Grass pastures), and cocoa plantation.

317 We quantified the proportional availability area of a particular habitat. Then, we quantified the

318 observations of use in that habitat at the population level. We performed a graphical analysis with

319 these two variables, comparing the four discrete vegetation types' proportional use against each 320 habitat's proportional availability [60]. Using the HaviStat 2.4 free access program [10,61], we 321 explored the visual data to infer relative use and habitat preference between the categories compared 322 (vegetation types, months of different seasons). The greater the disproportion between these two 323 variables in the graph, the higher the preference [8]. Ultimately, a preference was determined when 324 the abundance exceeded the potential habitat area to be used (availability); otherwise, there is use 325 and no preference [2,8]. As stated by [62], "resource selection" can be established when the resource 326 use is disproportionately greater than resource availability; this is assumed correlated with the 327 animal's fitness [63].

328 To confirm the graphic approach to habitat use (presence of the species or its stages), habitat 329 preference (asymmetric distribution of resources), or non-use (non-presence of the species in the 330 habitat), five preference indices were calculated using the HaviStat 2.4 program, including Duncan's 331 index [64], Ivlev's Electivility Index [65], Bailey confidence interval [66], Alpha index [67,68], constant 332 resource rate (Constant Resources) [69], and Interpretation of II ([70]). The HaviStat 2.4 program 333 allows to: 1) check if the sample size is adequate (power, significance level, G-test, Chi-test, and 334 Cherry-test [71]), which is useful for generating inferences at the population level and proposing 335 management strategies [3]; 2) statistically compare field data (95\% confidence intervals); and 3) 336 estimate five niche amplitude indices (Standardized Shannon [72], Ivlev's Electivility Index [65], 337 Levins index [73], Standardized Levins Index [74], and Levins Index Standardized modified by [75]). 338 The niche width indices were applied to infer whether the habitat resources were used or 339 exploited uniformly (or asymmetrically) by the observed species and the conditions that allow its 340 survival there. In this study, we measured how much wider the spectrum of resources used was in 341 the habitat and how a species could potentially live in a broad range of conditions; this was indicated 342 by its relative abundance (proxy), and the number of habitats inhabited [14]. Regarding the latter, 
resources and conditions should be considered as a whole, without specific differentiation, which is

344 impossible.

There is not enough published information about $A$. mixtum regarding its life history and autoecology (species-resources-condition-habitat relationships) in the current literature. The Havistat program has been successfully employed in other biological research $[8,76-79]$. By reaching a consensus among the indices, it is possible to differentiate whether a species uses one habitat or several, and, therefore, its resources), if it prefers that habitat (or others) or strongly selects or avoids one or more particular habitats. According to [62], resources are "avoided" in a habitat when resource use (relative abundance) is disproportionately less than expected, based on the availability of that resource (potentially available habitat). Consequently, even avoided resources may still be used by 353 animals.

Therefore, we speak of a narrow niche for a tick, such as $A$. mixtum, if it only uses or prefers a few hosts to feed and develop, or has little tolerance to environmental variables (e.g., temperature). In the same way, the greater habitat use or preference (e.g., vegetation types) by a tick species (to survive, molt, oviposit, wait for a host and complete the life cycle) and the greater its tolerance to environmental variables, the greater its niche width will be. The previous is derived from specific adaptations to tolerate different conditions and take advantage of heterogeneous or ephemeral resources within each habitat (generalist species [11]).

\section{Mammal species observed in the four habitats}

First, the literature review was used to identify the mammal species most likely to be found in

364 the study area. Posters were made with photographs of these mammal species. They were shown to

365 the people who work, live, or manage the Matepantano farm to identify them photographically $(n=75$ people). In situ photographic evidence and videos taken by locals, as well as compatible feces, were

367 also used to confirm the species. A list was made of the domestic and wild hosts potentially present 368 on the farm. It was contrasted against the mammal species that, according to the literature, are 369 commonly parasitized by $A$. cajennense s.l. Similarly, qualitative indications were obtained of the 370 relative abundances of host populations for summer and winter. This information was collected for 
each of the four habitats compared. Moreover, hosts that use to getting closer to the campus buildings

372 and residences were included.

\section{Climatological analysis of the region}

The maximum and minimum range of oscillation of different key environmental variables was calculated for A. mixtum, representing its ecological amplitude (niche width). The species' adaptability to adjust to environmental changes and tolerance level to extreme abiotic values provided the broad spectrum of conditions in the habitats that allow it to survive, complete the life cycle, and persist. To this end, a 29-year analysis was made of the climatological data available (1975-2004) from two of the Colombian Institute of Hydrology, Meteorology, and Environmental Studies' (IDEAM in Spanish) meteorological stations, the IDEAM, main automatic telemetry weather station at the Yopal airport code 35215020- and the Yopal conventional pluviometric station -code 35210020. The consultation was made in 2019. Both stations are located in Yopal (03.05 N; $76.33 \mathrm{~W} ; 1,205$ m.a.s.I.), which is within a $20 \mathrm{~km}$ radius from the Matepantano farm. This information was complemented with the multi-

year analysis

(1981-2010)

provided

by the

IDEAM (available at

386 http://atlas.ideam.gov.co/visorAtlasClimatologico.html). Because of its spatial scale, we termed this 387 climate analysis "regional level."

\section{Local weather and microclimate information}

The regional information was complemented with data from a permanent station for 391 continuous climate recording located in the cocoa crop sampled at the Matepantano farm. This 392 station, called Davis, has registered for seven years (2012 to 2019, every 30 minutes) temperature, 393 relative humidity, solar radiation, solar energy, rainfall, and wind speed using a Davis-Vantage Pro2 394 unit located at an altitude of $1.2 \mathrm{~m}$ and $300 \mathrm{~m}$ from the Matepantano farm's main buildings. We also 395 calculated the range of oscillation (maximum and minimum value) of different key environmental 396 variables for the tick (ecological amplitude of $A$. mixtum). Because of its spatial scale, we termed this 397 climate analysis "local level." 
To determine the range of daily oscillation experienced by ticks at the microhabitat level, the

399 temperature, humidity, and solar irradiance were measured in situ in the Cocoa Crop, Star Grass

400 Paddock, and riparian forest in summer (February) and in the Cocoa Crop and King Grass Crop in

401 winter (August). Hobo S-THB-M8000 sensors were used for temperature (accuracy $\pm 0,2^{\circ} \mathrm{C}$ ) and

402 relative humidity (accuracy $\pm 2,5 \%$ ) and the Hobo S-LIB-MOO3 sensor for solar radiation (irradiance)

403 (accuracy $\pm 10 \mathrm{~W} / \mathrm{m}^{2}$ ). The measurements were taken $30 \mathrm{~cm}$ from the ground, every 30 seconds in

404 summer and every minute in winter. In summer, the variables were measured the morning (9.30 am

405 to $12 \mathrm{pm}$ ) of February $8^{\text {th }}, 2019$, in the cacao plantation, the afternoon $(2.30$ to $4.30 \mathrm{pm})$ of February

$4068^{\text {th }}$ and $9^{\text {th }}$ in the Star Grass paddock, and all day $(9.30$ am to $4.30 \mathrm{pm})$ on February $10^{\text {th }}$ in the riparian

407 forest. In winter, on August $16^{\text {th }}$, in the cocoa plantation and in King Grass crop on August $17^{\text {th }}$, the

408 same three variables were measured in the morning and/or the afternoon. The three climatic variables

409 were measured in winter at $30 \mathrm{~cm}$ above the ground and only for cocoa crop habitat within the leaf

410 litter (a refuge usually frequented by ticks).

\section{RESULTS}

\section{Overview of the relative abundance of stages of $\boldsymbol{A}$. mixtum}

The collected and taxonomically classified Amblyomma ticks corresponded to the species $A$.

415 mixtum. Nymphs dominated the relative abundance of $A$. mixtum in the summer season (February)

416 for all selected habitats with $59.7 \%(4,021 / 6,733)$, larvae had $37.6 \%(2,533 / 6,733)$, and adults a low

$4172.7 \%(179 / 6,733)$. Meanwhile, in winter (August), the captured population not only decreased by one

418 order of magnitude but was dominated by adults with $61.7 \%(164 / 266)$, in three of the four habitats

419 except the Star Grass paddock, followed by larvae with $30.1 \%$ (80/266), and with few nymphs $8.3 \%$

$420 \quad(22 / 266)$ (Table 2).

421

422 Table 2. Number of collected and identified $\boldsymbol{A}$. mixtum specimens according to collection 423 method, habitat type and stage.

(A) Collection carried out on February, 2019 (summer) 
bioRxiv preprint doi: https://doi.org/10.1101/2020.12.23.424125; this version posted December 23, 2020. The copyright holder for this preprint (which was not certified by peer review) is the author/funder, who has granted bioRxiv a license to display the preprint in perpetuity. It is made available under aCC-BY 4.0 International license.

\begin{tabular}{|c|c|c|c|c|c|c|c|}
\hline Collection method & Capture fraction* & Habitat & Larvae & Nymphs & Females & Males & TOTAL \\
\hline \multirow{4}{*}{$\mathrm{CO}_{2}$ traps } & $7 / 7$ & Star Grass Paddock & 205 & 431 & 17 & 3 & 656 \\
\hline & $5 / 5$ & King Grass Crop & 212 & 1,882 & 22 & 52 & 2,168 \\
\hline & $8 / 8$ & Riparian Forest & 532 & 757 & 39 & 24 & 1,352 \\
\hline & $4 / 4$ & Cocoa Crop & 61 & 729 & 10 & 5 & 805 \\
\hline \multicolumn{3}{|r|}{ Subtotal } & 1,010 & 3,799 & 88 & 84 & 4,981 \\
\hline \multirow{4}{*}{$\begin{array}{c}\text { Cloth dragging by } \\
\text { transects }\end{array}$} & $7 / 7$ & Star Grass Paddock & 198 & 37 & 0 & 0 & 235 \\
\hline & $6 / 6$ & King Grass Crop & 496 & 74 & 0 & 0 & 570 \\
\hline & $4 / 4$ & Riparian Forest & 214 & 38 & 2 & 0 & 254 \\
\hline & $5 / 5$ & Cocoa Crop & 615 & 73 & 4 & 1 & 693 \\
\hline \multicolumn{3}{|r|}{ Subtotal } & 1,523 & 222 & 6 & 1 & 1,752 \\
\hline \multicolumn{3}{|r|}{ TOTAL } & 2,533 & 4,021 & 94 & 85 & 6,733 \\
\hline
\end{tabular}

(B) Collection carried out on August, 2019 (Winter)

\begin{tabular}{|c|c|c|c|c|c|c|c|}
\hline Collection method & Capture fraction* & Habitat & Larvae & Nymphs & Females & Males & TOTAL \\
\hline \multirow{4}{*}{$\mathrm{CO}_{2}$ traps } & $2 / 8$ & Star Grass Paddock & 0 & 10 & 12 & 10 & 32 \\
\hline & $6 / 6$ & King Grass Crop & 0 & 4 & 28 & 27 & 59 \\
\hline & $11 / 12$ & Riparian Forest & 0 & 5 & 18 & 26 & 49 \\
\hline & $5 / 5$ & Cocoa Crop & 0 & 0 & 13 & 22 & 35 \\
\hline \multicolumn{3}{|r|}{ Subtotal } & 0 & 19 & 71 & 85 & 175 \\
\hline \multirow{4}{*}{$\begin{array}{l}\text { Cloth dragging by } \\
\text { transects }\end{array}$} & $2 / 5$ & Star Grass Paddock & 67 & 0 & 0 & 0 & 67 \\
\hline & $2 / 7$ & King Grass Crop & 13 & 0 & 1 & 0 & 14 \\
\hline & $3 / 4$ & Riparian Forest & 0 & 3 & 4 & 1 & 8 \\
\hline & $2 / 6$ & Cocoa Crop & 0 & 0 & 1 & 1 & 2 \\
\hline \multicolumn{3}{|r|}{ Subtotal } & 80 & 3 & 6 & 2 & 91 \\
\hline \multicolumn{3}{|r|}{ TOTAL } & 80 & 22 & 77 & 87 & 266 \\
\hline
\end{tabular}

424 (A) summer; (B) winter at thr Yopal (Casanare).

425 *Number of traps or transects with effective capture related to the total number of traps or transects that were located in each 426 habitat.

A. mixtum's three stages (larvae, nymphs, and adults) used all four habitats with different 429 proportions between the two periods of the year studied (Fig 3A and 3B and Table 2). In summer, $43040 \%(2,738 / 6,733)$ of $A$. mixtum ticks were found in the King Grass Crop, $23.9 \%(1,606 / 6,733)$ in the 431 Riparian Forest, $22.2 \%(1,498 / 6,733)$ in the Cocoa Crop, and 13.2\% $(891 / 6,733)$ in the Star Grass 
432 Paddock (Table 2). In winter, 37.2\% (99/266) of the ticks used the Star Grass Paddock, followed by $43327.4 \%(73 / 266)$ in the King Grass plantation, $21.4 \%(57 / 266)$ in the Riparian Forest, and $13.9 \%$ $434(37 / 266)$ in the Cocoa Crop (Table 2).

Figure 3. Abundance of $A$. mixtum in every sampled habitat according to the season in the Matepantano farm. (A). February of 2019 (summer). (B). August of 2019 (winter).

2-5). Only the adult stage of $A$. mixtum used all the habitats in summer and winter. Its absolute abundance remained relatively similar in both seasons. In the winter season, the nymphs did not use the Cocoa Crop habitat, and the larvae were absent in the Riparian Forest and Cocoa Crop habitats

443 (Figures 3B and 4B, and Tables 2-5). A. mixtum's gender ratio for the total adults in both periods 444 (females:males with 171:172) was 0.994.

Figure 4. Trend graphs to infer the use and habitat preference of $\boldsymbol{A}$. mixtum. These plots relate tick total abundance and tick stage abundance of both seasons, summer and winter, (as an equivalent of observed use of each habitat resources) (red bar $\square$; frequency on the $y^{\prime}$-axis on the right) and the potential or available area of the habitat that $A$. mixtum might use (blue bar $\square$; frequency on the $y$-axis on the left) at the Matepanano farm. In that way, the higher the red bar and the lower the blue bar, the greater the habitat preference. When the red bar barely exceed or equals the blue bar, the relationship is correspond to habitat usage. When the blue bar far surpasses the red bar, there is avoidance of such a habitat (see tables 3-5). (A).

452 Summer season. (A1) The mathematical index points out that $A$. mixtum uses all four habitats. In addition, $A$. mixtum population 453 (stage independent) uses three habitats and shows preference for 'Star Grass Paddock' and 'King Grass Crop', while it avoids 454 the 'Riparian Forest' habitat. (A2) Adults of A. mixtum prefer 'King Grass Crop', while they use the remainder habitats. (A3) 455 Nymphs of A. mixtum prefer 'King Grass Crop' and ' Cocoa Crop', they use 'Star Grass Paddock', but they avoid the 'Riparian 456 Forest' habitat. (A4) Larvae of A. mixtum prefers three habitats ('King Grass Crop', 'Cocoa Crop' and 'Star Grass Paddock'), 457 while they only use the 'Riparian Forest' habitat. (B). Winter season. (B1) A. mixtum population (stage independent) prefers 458 'King Grass Crop' and 'Star Grass Paddock', it uses 'Cocoa Crop' and avoids 'Riparian Forest'. (B2) Adults of $A$. mixtum prefer 459 'King Grass Crop' and 'Cacao Crop', while they use 'Star Grass Paddock' and 'Riparian Forest'. (B3) Nymphs of A. mixtum 460 uses 'Cocoa Crop', the prefer 'Star Grass Paddock' and 'King Grass Crop', and they avoids the 'Riparian Forest' habitat. (B4) 461 Larvae of $A$. mixtum only uses two out of four habitats, preferring 'Star Grass Paddock' and using 'King Grass Crop'. 
bioRxiv preprint doi: https://doi.org/10.1101/2020.12.23.424125; this version posted December 23, 2020. The copyright holder for this preprint (which was not certified by peer review) is the author/funder, who has granted bioRxiv a license to display the preprint in perpetuity. It is made available under aCC-BY 4.0 International license.

Table 3. Calculations of potential area and A. mixtum abundance within each habitat to obtain

\section{4 the observed use.}

\begin{tabular}{|c|c|c|c|c|c|c|c|c|c|c|c|c|}
\hline & \multicolumn{12}{|c|}{ (A) SUMMER } \\
\hline & & \multicolumn{4}{|c|}{ Categories of Independent Variable } & \multirow[b]{2}{*}{ Total } & \multirow[b]{2}{*}{$\begin{array}{l}\text { Valor Chi } \\
\text { (G-test) }\end{array}$} & \multirow[b]{2}{*}{$\begin{array}{l}\text { Valor p } \\
\text { (G-test) }\end{array}$} & \multirow[b]{2}{*}{$\begin{array}{l}\text { Valor } p \\
\text { (Chi-test) }\end{array}$} & \multirow[b]{2}{*}{ Est. Error } & \multicolumn{2}{|c|}{ Cherry test } \\
\hline & & $\begin{array}{l}\text { Cocoa } \\
\text { Crop }\end{array}$ & $\begin{array}{c}\text { Riparian } \\
\text { Forest }\end{array}$ & \begin{tabular}{|c|} 
Star Grass \\
Paddock
\end{tabular} & $\begin{array}{c}\text { King Grass } \\
\text { Crop }\end{array}$ & & & & & & $n^{*} p i>5$ & $n^{*}(1-p i)>5$ \\
\hline \multirow{11}{*}{$\begin{array}{c}\text { Observed } \\
\text { Use } \\
\text { x } \\
\text { Dependent } \\
\text { Variables }\end{array}$} & $\begin{array}{l}\text { Potential } \\
\text { Area }\left(\mathrm{m}^{2}\right)\end{array}$ & 59,940 & 450,552 & 54,968 & 13,245 & 578,705 & & & & & & \\
\hline & Total tick & 1,498 & 1,606 & 891 & 2,738 & 6,733 & $14,838.4$ & 0.0000 & 0.0000 & 0.0000 & Yes & Yes \\
\hline & Total adults & 20 & 65 & 20 & 74 & 179 & 338.7 & 0.0000 & 0.0000 & 0.0180 & Yes & Yes \\
\hline & Total nymphs & 802 & 795 & 468 & 1,956 & 4,021 & $11,019.2$ & 0.0000 & 0.0000 & 0.0010 & Yes & Yes \\
\hline & Total larvae & 676 & 746 & 403 & 708 & 2,533 & $3,788.5$ & 0.0000 & 0.0000 & 0.0010 & Yes & Yes \\
\hline & \multicolumn{12}{|c|}{ (B) WINTER } \\
\hline & $\begin{array}{l}\text { Potential } \\
\text { Area }\left(\mathrm{m}^{2}\right)\end{array}$ & 59,940 & 450,552 & 54,968 & 13,245 & 578,705 & & & & & & \\
\hline & Total tick & 37 & 57 & 99 & 73 & 266 & 309.1 & 0.0000 & 0.0000 & 0.0070 & Yes & Yes \\
\hline & Total adults & 37 & 49 & 22 & 56 & 164 & 163.5 & 0.0000 & 0.0000 & 0.0130 & Yes & Yes \\
\hline & Total nymphs & 0 & 8 & 10 & 4 & 22 & 24.7 & 0.0000 & 0.0000 & 0.0780 & No & Yes \\
\hline & Total larvae & 0 & 0 & 67 & 13 & 80 & 273.0 & 0.0000 & 0.0000 & 0.0200 & No & Yes \\
\hline
\end{tabular}

465 (A) summer calculations; (B) winter calculations at the Matepantano Farm (Yopal, Casanare, Colombia).

466

467 Table 4. Calculations of the best five habitat preferences indices for $A$. $m i x t u m$ in the

\section{Matepantano Farm.}

\begin{tabular}{|c|c|c|c|c|c|}
\hline \multicolumn{6}{|c|}{ (A) SUMMER } \\
\hline & \multicolumn{4}{|c|}{ HABITAT PREFERENCE INDICES } & \multirow[t]{2}{*}{ NOTES } \\
\hline & DUNCAN INDEX & & & & \\
\hline & \multicolumn{4}{|c|}{ Categories of Independent Variable } & \\
\hline & Cocoa Crop & Riparian Forest & $\begin{array}{c}\text { Star Grass } \\
\text { Paddock }\end{array}$ & King Grass Crop & \\
\hline Total tick abundance & 0.5 & 0.1 & 0.4 & 1.3 & \multirow{4}{*}{$\begin{array}{l}\text { Range: } 0 \text { to }+ \text { Inf. } \\
\text { If }>\mathbf{0 . 3}=\text { Preference } \\
\text { If }<0.3=\text { No Preference }\end{array}$} \\
\hline Total adults & 0.3 & 0.2 & 0.3 & 1.3 & \\
\hline Total nymph & 0.5 & 0.1 & 0.4 & 1.3 & \\
\hline \multirow[t]{4}{*}{ Total larvae } & 0.6 & 0.1 & 0.4 & 1.1 & \\
\hline & \multicolumn{4}{|c|}{ IVLEV'S ELECTIVITY INDEX [65] } & \\
\hline & \multicolumn{4}{|c|}{ Categories of Independent Variable } & \\
\hline & Cocoa Crop & Riparian Forest & $\begin{array}{c}\text { Star Grass } \\
\text { Paddock }\end{array}$ & King Grass Crop & \\
\hline Total tick abundance & 0.4 & -0.5 & 0.2 & 0.9 & \multirow{4}{*}{$\begin{array}{l}\text { Range: }-1 \text { to }+1 \\
\text { If }>\mathbf{0}=\text { Preference } \\
\text { If }<0=\text { No Preference }\end{array}$} \\
\hline Total adults & 0.0 & -0.4 & 0.1 & 0.9 & \\
\hline Total nymph & 0.3 & -0.6 & 0.1 & 0.9 & \\
\hline Total larvae & 0.4 & -0.5 & 0.3 & 0.8 & \\
\hline
\end{tabular}


bioRxiv preprint doi: https://doi.org/10.1101/2020.12.23.424125; this version posted December 23, 2020. The copyright holder for this preprint (which was not certified by peer review) is the author/funder, who has granted bioRxiv a license to display the preprint in perpetuity. It is made available under aCC-BY 4.0 International license.

\begin{tabular}{|c|c|c|c|c|c|}
\hline & \multicolumn{4}{|c|}{ BAILEY CONFIDENCE INTERVALS [66] } & \\
\hline & \multicolumn{4}{|c|}{ Categories of Independent Variable } & \\
\hline & Cocoa Crop & Riparian Forest & $\begin{array}{c}\text { Star Grass } \\
\text { Paddock }\end{array}$ & King Grass Crop & \\
\hline Total tick abundance & 697.4 & $5,242.0$ & 639.5 & 154.1 & \multirow{4}{*}{$\begin{array}{l}\text { If upper Interval }<\text { Species Use = Preference } \\
\text { If Lower interval }>\text { Species Use }=\text { No Preference } \\
\text { If Lower Interval }<\text { Species Use }<\text { Upper Interval = Use }\end{array}$} \\
\hline Total adults & 18.5 & 139.4 & 17.0 & 4.1 & \\
\hline Total nymph & 416.5 & $3,130.6$ & 381.9 & 92.0 & \\
\hline \multirow[t]{4}{*}{ Total larvae } & 262.4 & $1,972.1$ & 240.6 & 58.0 & \\
\hline & \multicolumn{4}{|c|}{ ALPHA INDEX $[67,68]$ (CONSTANT RESOURCES [69]) } & \\
\hline & \multicolumn{4}{|c|}{ Categories of Independent Variable } & \\
\hline & Cocoa Crop & Riparian Forest & $\begin{array}{c}\text { Star Grass } \\
\text { Paddock }\end{array}$ & King Grass Crop & \\
\hline Total tick abundance & 0.1 & 0.0 & 0.1 & 0.8 & Range: 0 to +1 \\
\hline Total adults & 0.1 & 0.0 & 0.1 & 0.9 & If $>1 /$ (\#Indep. Var. $)=$ Preference \\
\hline Total nymph & 0.1 & 0.0 & 0.0 & 0.9 & If $<1 /$ (\#Indep. Var. $)=$ No Prefererence \\
\hline \multirow[t]{4}{*}{ Total larvae } & 0.2 & 0.0 & 0.1 & 0.7 & $1 /(\#$ Indep. Var. $)=0.25$ \\
\hline & \multicolumn{4}{|c|}{ INTERPRETATION OF II [70] } & \\
\hline & \multicolumn{4}{|c|}{ Categories of Independent Variable } & \multirow{7}{*}{$\begin{array}{l}\text { Range: }-1 \text { to }+1 \\
\text { If }-1<\text { Index Value }<-0.5=\text { Strong Avoidance } \\
\text { If }-0.49<\text { Index Value }<-0.26=\text { Moderate Avoidance } \\
\text { If }-0.25<\text { Index Value }<0.25=\text { Indiference } \\
\text { If } 0.26<\text { Index Value }<0.49=\text { Neutral Selection } \\
\text { If } 0.50<\text { Index Value }<1=\text { Strong Selection }\end{array}$} \\
\hline & Cocoa Crop & Riparian Forest & $\begin{array}{c}\text { Star Grass } \\
\text { Paddock }\end{array}$ & King Grass Crop & \\
\hline Total tick abundance & 0.4 & -0.8 & 0.2 & 0.9 & \\
\hline Total adults & 0.0 & -0.7 & 0.1 & 0.9 & \\
\hline Totalnymnh & 84 & 80 & & 10 & \\
\hline Total nymph & 0.4 & -0.9 & 0.1 & & \\
\hline Total larvae & 0.5 & -0.8 & 0.3 & 0.9 & \\
\hline \multicolumn{6}{|c|}{ (B) WINTER } \\
\hline & \multicolumn{4}{|c|}{ HABITAT PREFERENCE INDICES } & NOTES \\
\hline & \multicolumn{4}{|c|}{ DUNCAN INDEX [64] } & \\
\hline & \multicolumn{4}{|c|}{ Categories of Independent Variable } & \\
\hline & Cocoa Crop & Riparian Forest & $\begin{array}{c}\text { Star Grass } \\
\text { Paddock }\end{array}$ & King Grass Crop & \\
\hline Total tick abundance & 0.3 & 0.1 & 0.6 & 0.8 & Range: 0 to + Inf. \\
\hline Total adults & 0.4 & 0.2 & 0.3 & 0.9 & If $>0.3=$ Preference \\
\hline Total nymph & - & 0.2 & 0.6 & 0.7 & If $<0.3=$ No Preference \\
\hline \multirow[t]{4}{*}{ Total larvae } & - & - & 0.9 & 0.6 & - = absence of individuals \\
\hline & \multicolumn{4}{|c|}{ IVLEV'S ELECTIVITY INDEX [65] } & \\
\hline & \multicolumn{4}{|c|}{ Categories of Independent Variable } & \\
\hline & Cocoa Crop & Riparian Forest & $\begin{array}{c}\text { Star Grass } \\
\text { Paddock }\end{array}$ & King Grass Crop & \\
\hline Total tick abundance & -0.1 & -0.5 & 0.5 & 0.7 & Range: -1 to +1 \\
\hline Total adults & 0.2 & -0.4 & 0.0 & 0.7 & If $>0=$ Preference \\
\hline Total nymph & - & -0.3 & 0.5 & 0.6 & If $<0=$ No Preference \\
\hline \multirow[t]{3}{*}{ Total larvae } & - & - & 0.7 & 0.5 & - = absence of individuals \\
\hline & \multicolumn{4}{|c|}{ BAILEY CONFIDENCE INTERVALS [66] } & \\
\hline & \multicolumn{4}{|c|}{ Categories of Independent Variable } & \\
\hline
\end{tabular}


bioRxiv preprint doi: https://doi.org/10.1101/2020.12.23.424125; this version posted December 23, 2020. The copyright holder for this preprint (which was not certified by peer review) is the author/funder, who has granted bioRxiv a license to display the preprint in perpetuity. It is made available under aCC-BY 4.0 International license.

\begin{tabular}{|c|c|c|c|c|c|}
\hline & Cocoa Crop & Riparian Forest & $\begin{array}{c}\text { Star Grass } \\
\text { Paddock }\end{array}$ & King Grass Crop & \\
\hline Total tick abundance & 41.1 & 175.0 & 36.4 & 13.5 & \multirow{4}{*}{$\begin{array}{l}\text { If upper Interval }<\text { Species Use = Preference } \\
\text { If Lower interval }>\text { Species Use = No Preference } \\
\text { If Lower Interval }<\text { Species Use }<\text { Upper Interval = Use } \\
\text { - = absence of individuals }\end{array}$} \\
\hline Total adults & 25.4 & 107.9 & 22.5 & 8.3 & \\
\hline Total nymph & - & 14.5 & 3.0 & 1.1 & \\
\hline \multirow[t]{4}{*}{ Total larvae } & - & - & 11.0 & 4.1 & \\
\hline & \multicolumn{4}{|c|}{ ALPHA INDEX $[67,68]$ (CONSTANT RESOURCES [69]) } & \\
\hline & \multicolumn{4}{|c|}{ Categories of Independent Variable } & \multirow{6}{*}{$\begin{array}{l}\text { Range: } 0 \text { to }+1 \\
\text { If }>1 /(\# \text { Independent Variable })=\text { Preference } \\
\text { If }<1 /(\# \text { Independent Variable })=\text { No Prefererence } \\
1 /(\# \text { Independent Variable })=0.25 \\
-=\text { absence of individuals }\end{array}$} \\
\hline & Cocoa Crop & Riparian Forest & $\begin{array}{l}\text { Star Grass } \\
\text { Paddock }\end{array}$ & King Grass Crop & \\
\hline Total tick abundance & 0.1 & 0.0 & 0.3 & 0.6 & \\
\hline Total adults & 0.2 & 0.0 & 0.1 & 0.7 & \\
\hline Total nymph & - & 0.1 & 0.4 & 0.5 & \\
\hline \multirow[t]{5}{*}{ Total larvae } & - & - & 0.7 & 0.3 & \\
\hline & \multicolumn{4}{|c|}{ INTERPRETATION OF II [70] } & \\
\hline & & & & & Range: -1 to +1 \\
\hline & \multicolumn{4}{|c|}{ Categories of Independent Variable } & If $-1<$ Index Value $<-0.5$ = Strong Avoidance \\
\hline & Cocoa Crop & Riparian Forest & $\begin{array}{c}\text { Star Grass } \\
\text { Paddock }\end{array}$ & King Grass Crop & If $-0.49<$ Index Value $<-0.26=$ Moderate Avoidance \\
\hline Total tick abundance & -0.1 & -0.8 & 0.6 & 0.8 & If $-0.25<$ Index Value $<0.25=$ Indiference \\
\hline Total adults & 0.2 & -0.6 & 0.0 & 0.8 & If $0.26<$ Index Value $<0.49=$ Neutral Selection \\
\hline Total nymph & - & -0.5 & 0.7 & 0.6 & If $0.50<$ Index Value $<1$ = Strong Selection \\
\hline Total larvae & - & - & 0.9 & 0.6 & - = absence of individuals \\
\hline
\end{tabular}

469 (A) summer calculations; (B) winter calculations using HaviStat 2.4 ${ }^{\circledast}$. Potential area $\left(\mathrm{m}^{2}\right)$ for each habitat and tick abundance

470 were used from Table 3 for each index calculation.

471

472 Table 5. Calculations of the best five niche amplitud indices for $\boldsymbol{A}$. mixtum within its habitats

\section{3 in the Matepantano Farm.}

\begin{tabular}{|c|c|c|c|c|c|c|}
\hline \multicolumn{7}{|c|}{ (A) SUMMER } \\
\hline & \multicolumn{5}{|c|}{ NICHE AMPLITUDE INDICES } & NOTES \\
\hline & \multicolumn{5}{|c|}{ STANDARDIZED SHANNON INDEX [72] } & \\
\hline & \multicolumn{4}{|c|}{ Categories of Independent Variable } & \multirow{3}{*}{$\begin{array}{l}\text { Index } \\
\text { Value }\end{array}$} & \multirow{3}{*}{$\begin{aligned} \text { Bolded value } & =\text { maximum } \text { amplitude } \\
\text { Italize value } & =\text { minimum amplitude }\end{aligned}$} \\
\hline & Cocoa Crop & Riparian Forest & Star Grass Paddock & King Grass Crop & & \\
\hline Potential Area $\left(\mathrm{m}^{2}\right)$ & 59,940 & 450,552 & 54,968 & 13,245 & & \\
\hline Total tick abundance & 1,498 & 1,606 & 891 & 2,738 & 0.94 & \multirow{4}{*}{$\begin{array}{l}\text { Range: } 0 \text { to }+1 \\
0=\text { minimum niche amplitude } \\
+1 \text { =maximum niche amplitude }\end{array}$} \\
\hline Total adults & 20 & 65 & 20 & 74 & 0.88 & \\
\hline Total nymphs & 802 & 795 & 468 & 1,956 & 0.90 & \\
\hline \multirow[t]{4}{*}{ Total larvae } & 676 & 746 & 403 & 708 & 0.98 & \\
\hline & \multicolumn{4}{|c|}{ IVLEV'S ELECTIVITY INDEX [65] } & & \\
\hline & \multicolumn{4}{|c|}{ Categories of Independent Variable } & & \\
\hline & Cocoa Crop & \begin{tabular}{|l|} 
Riparian Forest \\
\end{tabular} & Star Grass Paddock & King Grass Crop & & \\
\hline Potential Area $\left(\mathrm{m}^{2}\right)$ & 59,940 & 450,552 & 54,968 & 13,245 & & \\
\hline
\end{tabular}


bioRxiv preprint doi: https://doi.org/10.1101/2020.12.23.424125; this version posted December 23, 2020. The copyright holder for this preprint (which was not certified by peer review) is the author/funder, who has granted bioRxiv a license to display the preprint in perpetuity. It is made available under aCC-BY 4.0 International license.

\begin{tabular}{|c|c|c|c|c|c|c|}
\hline Total tick abundance & 1,498 & 1,606 & 891 & 2,738 & 1.95 & \multirow{4}{*}{$\begin{array}{l}\text { Range: } 0 \text { to }+ \text { infinite } \\
0=\text { maximum niche amplitude } \\
\text { +infinite = minimum niche amplitude }\end{array}$} \\
\hline Total adults & 20 & 65 & 20 & 74 & 1.38 & \\
\hline Total nymphs & 802 & 795 & 468 & 1,956 & 1.92 & \\
\hline \multirow[t]{4}{*}{ Total larvae } & 676 & 746 & 403 & 708 & 1.99 & \\
\hline & LEVINS INDEX [7 & & & & & \\
\hline & & gories of Indepen & dent Variable & & & \\
\hline & Cocoa Crop & Riparian Forest & Star Grass Paddock & King Grass Crop & & \\
\hline Potential Area $\left(\mathrm{m}^{2}\right)$ & 59,940 & 450,552 & 54,968 & 13,245 & & \\
\hline Total tick abundance & 1,498 & 1,606 & 891 & 2,738 & 1.31 & \multirow{4}{*}{$\begin{array}{l}\text { Range: } 0 \text { to }+2 \\
0=\text { minimum niche amplitude } \\
+2=\text { maximum niche amplitude }\end{array}$} \\
\hline Total adults & 20 & 65 & 20 & 74 & 1.22 & \\
\hline Total nymphs & 802 & 795 & 468 & 1,956 & 1.24 & \\
\hline \multirow[t]{4}{*}{ Total larvae } & 676 & 746 & 403 & 708 & 1.36 & \\
\hline & STANDARDIZED & EVINS INDEX [74] & & & & \\
\hline & & gories of Indepen & dent Variable & & & \\
\hline & Cocoa Crop & Riparian Forest & Star Grass Paddock & King Grass Crop & & \\
\hline Potential Area $\left(\mathrm{m}^{2}\right)$ & 59,940 & 450,552 & 54,968 & 13,245 & & \\
\hline Total tick abundance & 1,498 & 1,606 & 891 & 2,738 & 0.82 & \multirow{4}{*}{$\begin{array}{l}\text { Range: } 0 \text { to }+1 \\
0=\text { minimum niche amplitude } \\
+1 \text { = maximum niche amplitude }\end{array}$} \\
\hline Total adults & 20 & 65 & 20 & 74 & 0.68 & \\
\hline Total nymphs & 802 & 795 & 468 & 1,956 & 0.68 & \\
\hline \multirow[t]{4}{*}{ Total larvae } & 676 & 746 & 403 & 708 & 0.94 & \\
\hline & \multicolumn{4}{|c|}{ MODIFIED STANDARDIZED LEVINS INDEX [75] } & & \\
\hline & \multicolumn{4}{|c|}{ Categories of Independent Variable } & & \\
\hline & Cocoa Crop & Riparian Forest & Star Grass Paddock & King Grass Crop & & \\
\hline Potential Area $\left(\mathrm{m}^{2}\right)$ & 59,940 & 450,552 & 54,968 & 13,245 & & \\
\hline Total tick abundance & 1,498 & 1,606 & 891 & 2,738 & 0.86 & \multirow{4}{*}{$\begin{array}{l}\text { Range: }(1 / \text { Independent Variable }) \text { to }+1 \\
(1 / \text { Independent } \text { Variable })=\text { minimum } \\
+1 \text { = maximum niche amplitude }\end{array}$} \\
\hline Total adults & 20 & 65 & 20 & 74 & 0.76 & \\
\hline Total nymphs & 802 & 795 & 468 & 1,956 & 0.76 & \\
\hline Total larvae & 676 & 746 & 403 & 708 & 0.96 & \\
\hline \multicolumn{7}{|c|}{ (B) WINTER } \\
\hline & \multicolumn{5}{|c|}{ NICHE AMPLITUDE INDICES } & NOTES \\
\hline & \multicolumn{4}{|c|}{ STANDARDIZED SHANNON INDEX [72] } & & \\
\hline & \multicolumn{4}{|c|}{ Categories of Independent Variable } & & \\
\hline & Cocoa Crop & Riparian Forest & Star Grass Paddock & King Grass Crop & \multirow{2}{*}{$\begin{array}{l}\text { Index } \\
\text { Value }\end{array}$} & Bolded value $=$ maximum amplitude \\
\hline Potential Area $\left(\mathrm{m}^{2}\right)$ & 59,940 & 450,552 & 54,968 & 13,245 & & Italize value $=$ minimum amplitude \\
\hline Total tick abundance & 37 & 57 & 99 & 73 & 0.96 & \multirow{4}{*}{$\begin{array}{l}\text { Range: } 0 \text { to }+1 \\
0=\text { minimum niche amplitude } \\
+1 \text { =maximum niche amplitude } \\
-=\text { absence of individuals }\end{array}$} \\
\hline Total adults & 37 & 49 & 22 & 56 & 0.96 & \\
\hline Total nymphs & - & 8 & 10 & 4 & 0.75 & \\
\hline \multirow[t]{4}{*}{ Total larvae } & - & - & 67 & 13 & 0.32 & \\
\hline & \multicolumn{4}{|c|}{ IVLEV'S ELECTIVITY INDEX [65] } & & \\
\hline & & gories of Indepen & dent Variable & & & \\
\hline & Cocoa Crop & Riparian Forest & Star Grass Paddock & King Grass Crop & & \\
\hline Potential Area $\left(\mathrm{m}^{2}\right)$ & 59,940 & 450,552 & 54,968 & 13,245 & & \\
\hline Total tick abundance & 37 & 57 & 99 & 73 & 1.71 & Range: 0 to +infinite \\
\hline Total adults & 37 & 49 & 22 & 56 & 1.31 & $0=$ maximum niche amplitude \\
\hline Total nymphs & - & 8 & 10 & 4 & 2.39 & +infinite $=$ minimum niche amplitude \\
\hline
\end{tabular}


bioRxiv preprint doi: https://doi.org/10.1101/2020.12.23.424125; this version posted December 23, 2020. The copyright holder for this preprint (which was not certified by peer review) is the author/funder, who has granted bioRxiv a license to display the preprint in perpetuity. It is made available under aCC-BY 4.0 International license.

\begin{tabular}{|c|c|c|c|c|c|c|}
\hline Total larvae & - & - & 67 & 13 & 3.24 & - = absence of individuals \\
\hline & \multicolumn{4}{|c|}{ LEVINS INDEX [73] } & & \\
\hline & \multicolumn{4}{|c|}{ Categories of Independent Variable } & & \\
\hline & Cocoa Crop & Riparian Forest & Star Grass Paddock & King Grass Crop & & \\
\hline Potential Area $\left(\mathrm{m}^{2}\right)$ & 59,940 & 450,552 & 54,968 & 13,245 & & \\
\hline Total tick abundance & 37 & 57 & 99 & 73 & 1.33 & Range: 0 to +2 \\
\hline Total adults & 37 & 49 & 22 & 56 & 1.33 & $0=$ minimum niche amplitude \\
\hline Total nymphs & - & 8 & 10 & 4 & 1.04 & +2 = maximum niche amplitude \\
\hline \multirow[t]{4}{*}{ Total larvae } & - & - & 67 & 13 & 0.44 & - = absence of individuals \\
\hline & \multicolumn{4}{|c|}{ STANDARDIZED LEVINS INDEX [74] } & & \\
\hline & \multicolumn{4}{|c|}{ Categories of Independent Variable } & & \\
\hline & Cocoa Crop & Riparian Forest & Star Grass Paddock & King Grass Crop & & \\
\hline Potential Area $\left(\mathrm{m}^{2}\right)$ & 59,940 & 450,552 & 54,968 & 13,245 & & \\
\hline Total tick abundance & 37 & 57 & 99 & 73 & 0.86 & Range: 0 to +1 \\
\hline Total adults & 37 & 49 & 22 & 56 & 0.88 & $0=$ minimum niche amplitude \\
\hline Total nymphs & - & 8 & 10 & 4 & 0.56 & +1 = maximum niche amplitude \\
\hline \multirow[t]{4}{*}{ Total larvae } & - & - & 67 & 13 & 0.12 & - = absence of individuals \\
\hline & \multicolumn{4}{|c|}{ MODIFIED STANDARDIZED LEVINS INDEX [75] } & & \\
\hline & \multicolumn{4}{|c|}{ Categories of Independent Variable } & & \\
\hline & Cocoa Crop & Riparian Forest & Star Grass Paddock & King Grass Crop & & \\
\hline Potential Area $\left(\mathrm{m}^{2}\right)$ & 59,940 & 450,552 & 54,968 & 13,245 & & \\
\hline Total tick abundance & 37 & 57 & 99 & 73 & 0.90 & Range: (1/Independent Variable) to +1 \\
\hline Total adults & 37 & 49 & 22 & 56 & 0.91 & $(1 /$ Independent Variable $)=$ minimum \\
\hline Total nymphs & - & 8 & 10 & 4 & 0.67 & $+1=$ maximum niche amplitude \\
\hline Total larvae & - & - & 67 & 13 & 0.34 & - = absence of individuals \\
\hline
\end{tabular}

In total, 2.8 times more ticks were caught with $\mathrm{CO}_{2}$ traps $(4,981)$ than with white flannelettes

477 transects $(1,752)$ in the summer time. In winter, the $\mathrm{CO}_{2}$ traps' effectiveness for tick collection 478 decreased 1.9 times (175 individuals) compared to the transects (91 individuals). The flannel dragging 479 method in the pre-determined transects was most effective in capturing the larvae in summer and 480 winter compared to the remnant stages (Table 2). Up to 17 times more nymphs and 25 times more 481 adults were collected using the $\mathrm{CO}_{2}$ traps than in the transects in summer. Similarly, six times more 482 nymphs and 20 times more adults were captured in winter using $\mathrm{CO}_{2}$ traps than flannel dragging. In 483 all habitats, $\mathrm{CO}_{2}$ traps were more effective in collecting ticks in summer; in winter, they were effective 484 in $75 \%$ of the habitats. The transects only outperformed the traps in capturing ticks in the Star Grass 485 paddock habitat in winter (Table 2). 


\section{Habitat use and preference}

The Cherry Test [71] indicated that in summer and winter the total sample of $A$. mixtum ticks

489 captured was sufficient to infer on the use and preference (Table 3). It should be noted that, during

490 the winter season, nymphs were absent from sampling in the cocoa plantation habitat and larvae

491 were not found in the cocoa plantation and riparian forest habitats. Duncan's Preference Indexes [64],

492 of Ivlev's electivity [65], Bailey's confidence interval [66], Alpha [67,68] (Constant Resources [69]),

493 and Interpretation of II $[70,74]$ indicated that, the A. mixtum population used all four habitats (Figure

4944 and Table 4). Moreover, most of these indices indicated A. mixtum's preference for three of the four

495 habitats (King Grass Crop, Cocoa Crop, and Star Grass Paddock).

496 A. mixtum uses, but does not prefer, the Riparian Forest habitat. This result was consistent

497 for nymphs, larvae, and adults, which was corroborated by the interpretation of II index that indicated

498 a strong avoidance of this habitat (Table 5). Although adults also preferred the King Grass plantation

499 habitat in both seasons, according to all selected indices, in summer, they used, but did not prefer

500 the cocoa plantation and Star Grass Paddock, according to four of the five indices (Table 4). In winter,

501 the concordance of non-preference of adults decreases between indices with respect to the habitat

502 'Cocoa Crop' but remains with respect to 'Star Grass Paddock'. The interpretation index of II shows

503 a strong avoidance of the habitat 'Riparian Forest ' by the adults (Table 4). In the case of larvae and

504 nymphs in summer the concordance of preference between indices is not complete either. Larvae

505 and nymphs prefer three of the four habitats according to three of the five selected indices. In winter

506 the five indices coincided in indicating preference of the immature stages for the habitats 'Star Grass

507 Paddock' and ' King Grass Crop' (Table 4).

508

509 Niche width

510 In summer, the niche amplitude was maximum for the larvae in four of the five indices, as the

511 value of Ivlev's electivity index was the lowest. In general, the rates of niche width obtained in this

512 part of the year are considered high for all free-living stages of $A$. mixtum, as well as the population

513 as a whole, since the values obtained tend towards the maximum amplitude (Table 5) $[65,72,73,75]$. 
514 Interestingly, during the winter season, the five selected indices coincided in a maximum niche

515 amplitude for the adult stage (Table 5), which also coincides with similar abundance data for adults

516 in the two sampled seasons (Table 2). That is, in summer and winter the survival rate of adults was

517 similar and could indicate that adults are present at different times throughout the year. In contrast,

518 the population of larvae and nymphs almost succumbed in winter, reducing their numbers by one

519 order of magnitude when compared to their collection in summer and disappearing from the 'Cocoa

520 Plantation' habitat. The larvae were also not found in the 'Riparian Forest' habitat (Figure 3 and Table

$5212)$.

522 Remarkably, the larvae in winter obtained the lowest niche amplitude in all the selected

523 indices (Table 5). This suggests that adults and immature A. mixtum would have differentiated

524 tolerance to abiotic conditions and different biotic relationships or behaviors in the studied habitats.

525 Events derived from winter weather behavior (e.g., prolonged flooding; favorable conditions for the

526 development of natural enemies such as fungi; scarcity of resources) could configure a greater

527 vulnerability for larvae and nymphs in 'Cocoa Crop', 'Riparian Forest' and 'King Grass Crop' (Figure

528 3). Therefore, the seasonality observed at the Matepantano farm, and its climatic and environmental

529 variability, may affect the use, preference and extent of the niche of the free-living stages of $A$. mixtum

530 that, which respond differently to the habitat.

\section{Climate of the region in summer and winter}

Wide seasonal variation of ambient temperature is observed in the region of up to $12{ }^{\circ} \mathrm{C}$ on average between the summer and winter seasons (Table 6) and an absolute range of $26^{\circ} \mathrm{C}$ at the

535 local weather station located in the 'Cocoa Plantation' habitat (Table 7). The temperature variation in

536 summer at the Matepantano farm is wider (from $18^{\circ} \mathrm{C}$ to $37^{\circ} \mathrm{C}$ ) when compared to the winter season

537 (minimum of $19^{\circ} \mathrm{C}$ and maximum of $33.6^{\circ} \mathrm{C}$ ). Total precipitation in winter (August) was one order of

538 magnitude higher than in summer (Table 7 ). The average relative humidity varied by $20 \%$ between

539 February and August, both in the regional (61 and 81\%) and local (68 and 88\%) climate seasons,

540 reaching minimum values of $30 \%$ in the summer season (Tables 6 and 7 ). 
bioRxiv preprint doi: https://doi.org/10.1101/2020.12.23.424125; this version posted December 23, 2020. The copyright holder for this preprint (which was not certified by peer review) is the author/funder, who has granted bioRxiv a license to display the preprint in perpetuity. It is made available under aCC-BY 4.0 International license.

Table 6. Multiannual mean range for several climatic variables recorded during 29 years (1975-

\section{2004) in two weather stations located at the Yopal municipality (Casanare, Colombia).}

\begin{tabular}{|c|c|c|}
\hline Variable & Range of the multiannual mean* & Observations \\
\hline Temperature $\left({ }^{\circ} \mathrm{C}\right)$ & $24-28$ & $\begin{array}{l}\text { The driest period was from November to March. } \\
\text { Maximum and minimum values of the multiannual } \\
\text { mean temperature during the } 29 \text { years period were } \\
33,7 \text { and } 30,1^{\circ} \mathrm{C} \text { for February, and } 23,8 \text { and } 21,7 \\
{ }^{\circ} \mathrm{C} \text { for August. }\end{array}$ \\
\hline Total precipitation (mm) & $2.500-3.000$ & $\begin{array}{l}\text { An unimodal rainfall cycle with a peak from April to } \\
\text { October. The maximum precipitation/day reached } \\
200 \mathrm{~mm} \text { in just one day. The multiannual mean } \\
\text { precipitation was } 16 \mathrm{~mm} \text { for February and } 97 \mathrm{~mm} \\
\text { for August. }\end{array}$ \\
\hline Evaporation (mm/year) & $1.300-1.500$ & Almost a half of the rainfall is evaporated. \\
\hline $\begin{array}{l}\text { Potential evapotranspiration } \\
\qquad \text { (mm/year) }\end{array}$ & $1.200-1.400$ & \\
\hline Relative humidity (\%) & $75-80$ & $\begin{array}{l}\text { Perhumid climatic type (Thornthwaite classification } \\
\text { Limit } 7 / 9 \text { ). Multiannual mean relative humidity } \\
\text { between } 1981 \text { to } 2010 \text { was } 61 \% \text { for February and } \\
81 \% \text { for August. }\end{array}$ \\
\hline Daily hours of sunligth & $5-6$ & \\
\hline $\begin{array}{l}\text { Daily solar irradiation } \\
\qquad\left(\mathrm{KW} / \mathrm{h} / \mathrm{m}^{2}\right)\end{array}$ & $4,5-5$ & \\
\hline Ultraviolet radiation (IUV) & $7-8$ & \\
\hline Soil net water $(\mathrm{mm})$ & $1.000-2.000$ & $\begin{array}{l}\text { Soil drought is common between the November to } \\
\text { January period. }\end{array}$ \\
\hline $\begin{array}{l}\text { Water excess in the annual } \\
\text { extreme (decades) }\end{array}$ & $15-20$ & \\
\hline $\begin{array}{l}\text { Water deficit in the annual } \\
\text { extreme (decades) }\end{array}$ & $5-10$ & \\
\hline Wind speed $(\mathrm{m} / \mathrm{s})$ & $3-4$ & $\begin{array}{l}\text { The prevailing wind direction at the study site was } \\
\text { East-West. }\end{array}$ \\
\hline
\end{tabular}

$544{ }^{*}$ Data delivered by IDEAM (IDEAM, [Climatic Atlas of Colombia, Interactive version, Bogotá, D.C., 2015, text in Spanish]

545 ISBN: Volume 1: 978-958-8067-73-5) corresponded to annual mean with annotations about variable behavior in every month. 
bioRxiv preprint doi: https://doi.org/10.1101/2020.12.23.424125; this version posted December 23, 2020. The copyright holder for this preprint (which was not certified by peer review) is the author/funder, who has granted bioRxiv a license to display the preprint in perpetuity. It is made available under aCC-BY 4.0 International license.

546 However, no access was obtain to original data in order to calculate maximum and minimum values of each variable during

547 those 29 years. NOTICE: According to IDEAM, the agroclimatic zone value of the study site has been $<0.6$ within the last three

548 decades.

549

550 Table 7. Multiannual mean of climatic variables recorded during seven years (2012-2019) in

551 the Matepantano farm.

\begin{tabular}{|c|c|c|c|c|c|}
\hline Variable* $^{*}$ & Mean (SD) & Max. & Min. & Difference & Observations \\
\hline $\begin{array}{l}\text { Annual temperature } \\
\qquad\left({ }^{\circ} \mathrm{C}\right)\end{array}$ & $25,9( \pm 3,5)$ & 41,9 & 15,9 & 26,0 & $\begin{array}{l}\text { Maximum value was recorded in } 2018 \text {, while } \\
\text { the minimum value was recorded in } 2015 \text {. }\end{array}$ \\
\hline $\begin{array}{l}\text { Temperatura }\left({ }^{\circ} \mathrm{C}\right) \text { in } \\
\text { February (summer) }\end{array}$ & $27,7( \pm 4,1)$ & 37,0 & 18,0 & 19,0 & \\
\hline $\begin{array}{l}\text { Temperatura }\left({ }^{\circ} \mathrm{C}\right) \text { in } \\
\text { August (winter) }\end{array}$ & $25,2( \pm 3,0)$ & 33,6 & 19,0 & 14,6 & \\
\hline $\begin{array}{c}\text { Total annual } \\
\text { precipitation }(\mathrm{mm})\end{array}$ & $1559,8( \pm 507,7)$ & 2251 & 619 & 1632 & $\begin{array}{l}\text { Maximum precipitation ( } 155 \mathrm{~mm} \text { in one day) } \\
\text { between July to November of } 2016 \text {. }\end{array}$ \\
\hline $\begin{array}{l}\text { Total precipitation } \\
(\mathrm{mm}) \text { in February }\end{array}$ & $23,7( \pm 37,7)$ & 105 & 0 & 105 & \\
\hline $\begin{array}{l}\text { Total precipitation } \\
(\mathrm{mm}) \text { in August }\end{array}$ & $366( \pm 104,3)$ & 481 & 193 & 288 & $\begin{array}{l}\text { It represents almost the third of the annual } \\
\text { total precipitation. }\end{array}$ \\
\hline $\begin{array}{l}\text { Relative humidity } \\
\qquad(\%)\end{array}$ & $83,4( \pm 13,6)$ & 100 & 30 & 70 & \\
\hline $\begin{array}{l}\text { Relative humidity } \\
(\%) \text { in February }\end{array}$ & $68,0( \pm 14,5)$ & 99 & 30 & 69 & \\
\hline $\begin{array}{l}\text { Relative humidity } \\
(\%) \text { in August }\end{array}$ & $88,3( \pm 8,6)$ & 100 & 50 & 50 & \\
\hline $\begin{array}{l}\text { Dew point } \\
\left({ }^{\circ} \mathrm{C}\right)\end{array}$ & $22,2( \pm 4,7)$ & 27,2 & 18,2 & 9 & \\
\hline $\begin{array}{l}\text { Solar irradiation } \\
\qquad\left(\mathrm{KW} / \mathrm{m}^{2}\right)\end{array}$ & $221,7( \pm 317,0)$ & 1447 & 0 & 1447 & \\
\hline $\begin{array}{l}\text { Solar energy } \\
\text {-radiant light and } \\
\text { heat- (Exajoules) }\end{array}$ & $3,3( \pm 6,3)$ & 46,6 & 0 & 46,6 & \\
\hline $\begin{array}{c}\text { Atmospheric } \\
\text { pressure (milibar) }\end{array}$ & $1.010( \pm 2)$ & & & & \\
\hline
\end{tabular}




\begin{tabular}{|c|c|c|c|c|c|}
\hline Wind speed $(\mathrm{m} / \mathrm{s})$ & $0,76( \pm 0,36)$ & 16,1 & 0 & 16,1 & $\begin{array}{l}\text { Often strong gust of wind in the N-NE and E } \\
\text { directions. } \\
\text { The strongest gust of wind between August to } \\
\text { November. Only throughout the } 2015 \text { year, the } \\
\text { wind direction was to the North. }\end{array}$ \\
\hline
\end{tabular}

*Data from the weather station located at the 'Cacao Crop' habitat ( $\mathrm{N}=242,152$ records).

NOTICE: A milimeter of water equals the emptying of one (1) liter of water in a $1 \mathrm{~m}^{2}$ surface of enclosed space (the water volume will have exactly $1 \mathrm{~mm}$ of thickness). So, the multiannual mean precipitation in February (summer) in the Matepantano farm is 23.7 litres $/ \mathrm{m}^{2}$ that is equal to $23.7 \mathrm{~mm}$ or around $2 \mathrm{~cm}$ of water over the ground. By contrast, the multiannual mean precipitation in August (winter) is 366 litres $/ \mathrm{m}^{2}$ (366 mm or almost $36 \mathrm{~cm}$ of water over the ground). It means around 15 times

\section{Microclimatic variables by habitat in summer}

\section{Cocoa Crop}

Solar radiation remained low and relatively constant $\left(<200 \mathrm{~W} / \mathrm{m}^{2}\right)$ in the morning and up to noon (Figure 5), with some very irregular readings $\left(200-800 \mathrm{~W} / \mathrm{m}^{2}\right)$ probably due to the sustained movement of the wind on the cocoa leaves that allowed intermittent, but direct, exposure to sunlight (Figure 5). In the afternoon, the solar radiation went from almost $500 \mathrm{~W} / \mathrm{m}^{2}$ up to approximately 200 $\mathrm{W} / \mathrm{m}^{2}$. Thus, the solar radiation can have variations of up to $400 \mathrm{~W} / \mathrm{m}^{2}$ in a few hours in the same day. The ambient temperature increased by $9^{\circ} \mathrm{C}$ (from 25 to about $34^{\circ} \mathrm{C}$ ) from early morning to midday. In the afternoon, the temperature drops from $38^{\circ} \mathrm{C}$ to $35^{\circ} \mathrm{C}$. That is, the temperature can vary up to $13^{\circ} \mathrm{C}$ in seven hours.

Figure 5. Plots of microclimatic variables that were measured in situ for three habitats. (A). 'Cocoa Crop' habitat. (A1). Solar irradiation values $\left(\mathrm{W} / \mathrm{m}^{2}\right)(\mathrm{N}=736 ; \bar{\chi}=243.5 ; \mathrm{SD}=189.1$; Max=810.6; Min=59.4) according to the daytime hours. (A2). Temperature values $\left({ }^{\circ} \mathrm{C} ;\right.$ red line $)(\mathrm{N}=901 ; \bar{\chi}=32.7 ; \mathrm{SD}=3.6 ; \mathrm{Max}=38.7 ; \mathrm{Min}=25.1)$ and relative humidity $(\%$; blue line $)(\mathrm{N}=901$; $\bar{\chi}=45.9 ; \mathrm{SD}=11.6$; Max=76.9; Min=30.4) according to the daytime hours. (B). 'Star Grass Paddock' habitat. (B1). Solar 574 irradiation values $\left(\mathrm{W} / \mathrm{m}^{2}\right)(\mathrm{N}=427 ; \bar{\chi}=629.1 ; \mathrm{SD}=199.6 ; \mathrm{Max}=1,096.9 ;$ Min=295.6) according to the daytime hours. (B2).

575 Temperature values $\left({ }^{\circ} \mathrm{C}\right.$; red line) $(\mathrm{N}=427 ; \bar{\chi}=35.6 ; \mathrm{SD}=0.8 ; \mathrm{Max}=37.2 ; \mathrm{Min}=32.4)$ and relative humidity (\%; blue line) $(\mathrm{N}=276 ; \bar{\chi}=34.4 ; \mathrm{SD}=1.0 ; \mathrm{Max}=38 ; \mathrm{Min}=32.3)$ according to the daytime hours. The relative humidity variable was not measured 
(C1). Solar irradiation values $\left(\mathrm{W} / \mathrm{m}^{2}\right)(\mathrm{N}=677 ; \bar{\chi}=36 ; \mathrm{SD}=19.8 ;$ Max=189.6; Min=6.9) according to the daytime hours. (C2).

Temperature values $\left({ }^{\circ} \mathrm{C}\right)(\mathrm{N}=677 ; \bar{\chi}=31.1 ; \mathrm{SD}=0.4 ; \mathrm{Max}=31.8 ; \mathrm{Min}=29.9)$ according to the daytime hours. The relative humidity

variable was not measured because of a damage in the respective sensor.

The relative humidity varied by $40 \%$ from the first part of the morning until midday, but in the

583 afternoon, it increased by almost $10 \%$ from $30 \%$. Thus, the relative humidity can vary up to $50 \%$ in a

584 single day in the habitat of 'Cocoa Crop' (Figure 5). This one-day variation was half of the variation recorded in seven years for temperature and $75 \%$ of the variation recorded multiyearly for humidity

586 (Table 7). Ticks in this environment should survive extremely low humidity conditions of up to $30 \%$

587 when there is more solar radiation. The relative humidity decreased as the temperature increased.

588 Higher values of relative humidity, early in the morning, coincided with observations of increased tick

589 activity and abundance in the dry ice traps at the time of capture.

\section{$591 \quad$ Star Grass Paddock}

Variations were between 1.100 and $300 \mathrm{~W} / \mathrm{m}^{2}$, which means a difference of $800 \mathrm{~W} / \mathrm{m}^{2}$, decreasing towards the sunset. On the other hand, the temperature remained high on average at

$59435^{\circ} \mathrm{C}$, decreasing little in the afternoon hours. Therefore, the range of variation was lower $\left(5^{\circ} \mathrm{C}\right)$ in the

595 afternoon than that observed in the morning for the habitat 'Cocoa Crop' at the same time (Figure 5).

596 The relative humidity in 'Star Grass Paddock' was low in summer, $34 \%$ on average and at least $32 \%$,

597 but equally the variation between extreme values was low, only 6\% (Figure 5).

\section{Riparian Forest}

In this habitat, solar irradiation was very low (one order of magnitude lower), with an average 601 of $36 \mathrm{~W} / \mathrm{m}^{2}$ and a variation between extreme values of $180 \mathrm{~W} / \mathrm{m}^{2}$ (Figure 5). This low penetration of 602 sunlight, due to the high coverage of the canopy, maintained a relatively constant temperature with 603 an average of $31^{\circ} \mathrm{C}$, varying only $2^{\circ} \mathrm{C}$. Unfortunately, due to damage to the humidity sensor, the respective values were not recorded that day. 


\section{Microclimatic variables by habitat in winter}

\section{Cocoa Crop}

Starting with a peak of $800 \mathrm{~W} / \mathrm{m}^{2}$ and then reaching a second peak above $600 \mathrm{~W} / \mathrm{m}^{2}$, the

609 solar irradiation remained relatively constant below $200 \mathrm{~W} / \mathrm{m}^{2}$ most of the time monitored. However,

610 the average irradiance was lower, almost half, than in summer (126 vs. $243 \mathrm{~W} / \mathrm{m}^{2}$; Figures 6 and 6 ).

611 The variation in temperature was also smaller in winter (just $5^{\circ} \mathrm{C}$ ) when compared to the summer

612 season. Likewise, the variation in relative humidity was also lower in winter with about $30 \%$ between

613 the extreme values when compared to $47 \%$ in summer (Figure 6).

\section{4}

615 Figure 6. Plots of microclimatic variables that were measured in situ for two habitats. (A). 'Cocoa Crop' habitat. (A1).

616 Solar irradiation values $\left(\mathrm{W} / \mathrm{m}^{2}\right)(\mathrm{N}=236 ; \bar{\chi}=126.4 ; \mathrm{SD}=118.3$; Max=798.1; Min=19.4) according to the daytime hours. (A2).

617 Temperature values $\left({ }^{\circ} \mathrm{C}\right.$; red line) $(\mathrm{N}=236 ; \bar{\chi}=28.6 ; \mathrm{SD}=1.0 ; \mathrm{Max}=32.2 ; \mathrm{Min}=27.0)$ and relative humidity (\%; blue line)

$618(\mathrm{~N}=236 ; \bar{\chi}=73.6 ; \mathrm{SD}=4,3 ; \mathrm{Max}=98.6$; Min=65.4) according to the daytime hours. (B). 'King Grass Crop' habitat. (B1). Solar

619 irradiation values $\left(\mathrm{W} / \mathrm{m}^{2}\right)(\mathrm{N}=396 ; \bar{\chi}=70.4 ; \mathrm{SD}=30.2 ;$ Max=164.4; Min=19.4) according to the daytime hours. (B2). Temperature

620 values $\left({ }^{\circ} \mathrm{C}\right.$; red line $(\mathrm{N}=457 ; \bar{\chi}=23.9 ; \mathrm{SD}=0.7 ; \mathrm{Max}=25,8 ; \mathrm{Min}=22.6)$ and relative humidity $(\% ;$ blue line $)(\mathrm{N}=457 ; \bar{\chi}=96.9 ;$

$621 \mathrm{SD}=2.3$; Max=100; Min=83.6) according to the daytime hours. (C). Litter at the 'Cocoa Crop' habitat. (C1). Solar irradiation

622 values $\left(\mathrm{W} / \mathrm{m}^{2}\right)(\mathrm{N}=101 ; \bar{\chi}=188.7 ; \mathrm{SD}=114.1 ; \mathrm{Max}=619.4 ; \mathrm{Min}=99.4)$ according to the daytime hours. (C2). Temperature values

$623\left({ }^{\circ} \mathrm{C}\right)(\mathrm{N}=101 ; \bar{\chi}=26,7 ; \mathrm{SD}=0,8 ; \mathrm{Max}=28,8 ; \mathrm{Min}=25,6)$ and relative humidity $(\%)(\mathrm{N}=117 ; \bar{\chi}=99.99 ; \mathrm{SD}=0.05 ; \mathrm{Max}=100 ;$

624 Min=99.6) according to the daytime hours.

\section{King Grass Crop}

Solar radiation was low with an average of $70 \mathrm{~W} / \mathrm{m}^{2}$ and a difference of $145 \mathrm{~W} / \mathrm{m}^{2}$ between

628 the extreme values recorded (cloudy day), which can be explained by the height of the King Grass

629 (about $2 \mathrm{~m}$ ) and the dense vegetation. In this sense, the humidity was very high at $30 \mathrm{~cm}$ from the

630 ground, between $83-100 \%$ with an average of $97 \%$ during that day (Figure 6). The range of

631 temperature variation throughout the day was also narrow with only $3^{\circ} \mathrm{C}$ and an average of $24^{\circ} \mathrm{C}$. 
The variables solar irradiation, temperature and humidity inside the litter, that is, between the

635 soil and the litter, were taken in order to compare the litter (a place used as a refuge by ticks because

636 its lower micro-environmental variation) with the 'Cocoa Crop' microenvironment at $30 \mathrm{~cm}$ from the

637 ground. Thus, the average temperature inside the leaf litter $(7 \mathrm{~cm}$ deep) was two degrees lower than

638 in the environment, and the variation between extreme values was narrower. This suggests more

639 stable and less extreme environmental conditions for the ticks that inhabit the litter. For its part, the

640 humidity was maximum within the litter, almost completely constant $(100 \%$ for most of the period

641 studied), and $26 \%$ lower than the average of the microenvironment (Figure 6). Although the

642 measurements were not simultaneous between the litter and the microclimate at $30 \mathrm{~cm}$ from the

643 ground, the solar irradiation remained below $200 \mathrm{~W} / \mathrm{m}^{2}$ most of the time in both environments,

644 indicating that sunlight reaches the leaf litter at a depth of $7 \mathrm{~cm}$.

645 Integrating the information from the sensors in all the habitats, with the aim of recreating the

646 behavior of the variables in a day, it can be pointed out that the environmental temperature follows a

647 normal distribution curve (except if it is cloudy or raining). The relative humidity shows a negative

648 exponential behavior during the day (except if it rains, where the humidity exceeds 96\%). The solar

649 irradiation was inversely proportional to the vegetation cover, i.e. the greater the tree canopy and the

650 greater the number of layers (Table 1), the less solar radiation will be registered by the sensor at 30

$651 \mathrm{~cm}$ from the ground. Thus, the average solar radiation captured in summer in the habitat of 'Star

652 Grass Paddock' was 2.5 times higher than that measured in 'Cocoa Crop' and more than 17 times

653 higher than in 'Riparian Forest'. In the same sense, the average room temperature was maximum in

654 'Star Grass Paddock' with $35.6^{\circ} \mathrm{C}$, being $3^{\circ} \mathrm{C}$ lower in 'Cocoa Crop' and more than $4^{\circ} \mathrm{C}$ lower in

655 'Riparian Forest'. Therefore, the climatic and microclimatic data show that, within the Matepantano

656 farm, A. mixtum lives in an environment with large daily, seasonal and multiannual fluctuations in

657 relative humidity, ambient temperature, solar radiation and precipitation.

659 Potential Hosts

A total of 20 mammals were identified as potential hosts on the farm, which they have seen

661 moving through the four habitats compared. $85 \%(17 / 20)$ of the animals were seen in 'Riparian 
662 Forest', $40 \%(8 / 20)$ in the area of administrative and residential buildings, $25 \%(5 / 20)$ in 'Star Grass

663 Paddock', 20\% (4/20) in 'Cocoa Crop', and 15\% in 'King Grass Crop' (Figure 7). Only 3 of the 20

664 animals were classified as domestic and the rest were wild mammals. Armadillos, chigüiros, horses

665 and cattle were identified by respondents as the species most frequently seen passing through the

666 farm and connecting all of the four habitats. Six species of animals (three domestic and three wild)

667 were the most seen mammals. Apart from the three species of domestic animals (cat, horse and

668 cow), 14 species of wild mammals in summer and 12 in winter were consistently observed by

669 respondents. It is interesting to note that summer was the time with the highest tick capture in our

670 study.

672 Figure 6. Potential host mammals of $\boldsymbol{A}$. mixtum in the habitats of the Matepantano farm. Color of every box (blue =

673 Riparian Forest; orange = Cocoa Crop; violet = King Grass Crop; green = Star Grass Paddock; black = administrative buildings;

674 bedrooms, classroom, and restaurant) represent every habitat and other areas where the potential host has been seen by

675 locals. Also, the sun symbol represents host presence in the summer season, while the rain clouds stands for host presence

676 in the winter season. The '+' symbol indicates the minimum perception of relative host abundance in the habitat, while the '+++'

677 represents the maximum perception. Note that host could have been seen in different habitats (several colored boxes). The

678 animals species identified by locals based on photographs and common names have been identified by numbers and

679 organized by rows from the left to the right and their common and scientific names (the last one between parentheses) are

680 written as follows: 1) Armadillo (Dasypus novemcinctus); 2) capybara (Hydrochaeris hydrochaeris); 3) porcupine (Coendou

681 prehensilis); 4) black agouti (Dasyprocta fuliginosa); 5) deer (Odocoileus virginianus); 6) flat-faced fruit-eating bat (Artibeus

682 planirostris); 7) anteater (Myrmecophaga tridactyla); 8) Seba's short-tailed bat (Carollia perspicillata); 9) fox (Urocyon

683 cinereoargenteus); 10) opossum (Didelphis marsupialis); 11) tufted capuchin (Cebus apella); 12) Colombian red howler

684 (Alouatta seniculus); 13) collared peccary (Pecari tajacu); 14) South American tapir (Tapirus terrestris); 15) southern tamandua

685 (Tamandua tetradactyla); 16) puma (Puma yagouaroundi); 17) margay (Leopardus wiedii); 18) cat (Felis catus); 19) cow (Bos

686 taurus indicus); 20) horse (Equus ferus caballus). Except for the last three species, all 17 animals seen by locals in the habitats

687 are wild species. Both domestic and wild animals use to be around the administrative buildings.

\section{Discussion}

The literature regarding empirical data on tolerance of $A$. mixum to different abiotic variables

691 is still incipient. Even so, the available data about A. mixtum in Texas (USA), Mexico and Panama

692 indicate that the species, in the field as well as in the laboratory, can tolerate high and low relative 
693 humidity, as well as high and low temperature (ranges: $35-95 \%$ and $18-36^{\circ} \mathrm{C}$; see S5 Table). The

694 thermal tolerance reported for $A$. mixtum coincides with our observations where the temperature

695 fluctuates strongly between the two times of the year studied (Dry season (February/2019) vs. rainy

696 season (August/2019)). In the Yopal region, the average temperature has been between 21 and $33^{\circ} \mathrm{C}$

697 for three decades (Table 6) and specifically at the Matepantano farm, between 18 and $37^{\circ} \mathrm{C}$, for the

698 last seven years (Table 7). We found that $A$. mixtum achieved the maximum niche width in summer,

699 with occupation of all selected habitats at microclimate temperatures (in one day) ranging from 25 to

$70038^{\circ} \mathrm{C}$ (Figure 5). In this way, the population of $A$. mixtum that we study could be favored by the wide

701 temperature changes that occur at different time scales (e.g. daily, monthly, seasonal and multi-year)

702 in the habitats.

703 In the same way, one model projected that $A$. mixtum in California does not find any suitable

704 habitat for the establishment of its populations, due to two related limitations, the low average

705 temperature of $10^{\circ} \mathrm{C}$ associated to high altitude [42]. Additionally, [80] did not find A. mixtum above

7061,200 m.a.s.I. in Panama, in places with less than $15^{\circ} \mathrm{C}$. The thermal limit has also been corroborated

707 by [81] where $50 \%$ of the adults of $A$. cajennense s.l. (renowned $A$. mixtum) died after 180 minutes

708 of exposure to $-12.5^{\circ} \mathrm{C}$, limiting for this group their spatial distribution in latitudes higher than $30^{\circ}$ [82].

709 From the above, it is inferred that the appropriate temperature in the habitats projected, used or

710 preferred by $A$. mixtum, can vary widely within extreme values $\left(>10-15^{\circ} \mathrm{C}\right)$ where the species is

711 favored. The elevation of the terrain is undoubtedly associated with the thermal gradient that in turn

712 determines the habitat that the species can occupy. The altitudinal distribution of $A$. mixtum in the

713 foothills of the Eastern Colombian Mountains and its negative association with low temperatures,

714 despite the presence of favorable hosts such as horses and cows, should be investigated to

715 understand the distribution of the species in Colombia and other countries.

716 On the other hand, the adaptation or phenotypic plasticity of $A$. mixtum to relative humidity

717 and temperature have important effects on their spatial distribution and habitat selection. Because of

718 its wide tolerance to these two variables, the geographical distribution of $A$. mixtum extends from

719 South Texas to the Pacific coast of Ecuador [48]. Additionally, [43] modeled the spatial distribution of

720 A. mixtum from the records of presence-absence in the Neotropics and projected the presence of this 
721 tick in areas with high temperature variability (including the Colombian Llanos Orientales), preferring

722 sustained high temperatures, within a narrow range of average annual temperatures $\left(\sim 19-33^{\circ} \mathrm{C}\right)$. The

723 Estrada-Peña et al. model [43] projects the habitat of the semi-desert madrense of Mexico as not

724 suitable for the establishment of A. mixtum. According to LandScope America (Available at:

725 http://www.landscope.org/explore/natural_geographies/divisions/madrean_semidesert/), the

726 Madrense semi-desert, which covers southern Texas and a substantial part of northern Mexico, has

727 an average annual temperature of $\sim 23^{\circ} \mathrm{C}$ and an annual precipitation of only $112 \mathrm{~mm}$ in the town of

728 Brownsville (Texas).

729 The other key variable for considering a suitable habitat for $A$. mixtum has to do with the 730 relative humidity $(\mathrm{RH})$. [81] showed that no female $A$. cajennense s.l. (renowned $A$. mixtum) survived 731 more than 1 month in very dry environments (35\% of $\mathrm{RH})$. Large fluctuations in relative humidity are 732 reported in our study region. The extreme minimum value recorded in 29 years for the Yopal region 733 was $61 \%$ and up to $30 \%$ relative humidity at Finca Matepantano (Tables 6 and 7, respectively).

734 Values below $40 \%$ relative humidity are not usually common or prolonged over time and there are no 735 data on their effect on the development, survival and population size of $A$. mixtum. [41] observed that 736 prolonged exposure to $56 \%$ relative humidity stimulated quiescence in some stages of this tick. [81] 737 recorded the death of all adults at $35 \%$ relative humidity and $33^{\circ} \mathrm{C}$ at the end of 30 days (S5 Table). 738 In our study in Matepantano farm, we found that the relative humidity fluctuates strongly within a few 739 hours in the same day and between seasons.

740 In summer, in the 'Cocoa Crop' habitat the relative humidity was low with an average of $46 \%$ 741 and very low in 'Star Grass Paddock' with an average of 34\% (Figure 5). In contrast in winter, the 742 relative humidity was high for 'Cocoa Crop' with 74\% average and very high for 'King Grass Crop' 743 with $97 \%$ average (Figure 6). This variable could be related to population density and stage relative 744 dominance. So, for example, we capture many more immature than adults from $A$. mixtum in summer, 745 but no immature and almost twice as many adults in winter in 'Cocoa Crop' (Figure 3). However, in 746 'Star Grass Paddock' the capture of immatures was about 20 times higher than that of adults in 747 summer; on the contrary, about five to 10 times less immature than adults were captured in 'King 748 Grass Crop' in winter (Figure 3). 
The results lead us to infer that a particular habitat is heterogeneous both in time and space

750 and that the leaf litter on the ground could help to minimize the low humidity of the environment, since

751 inside the leaf litter we measure higher relative humidity with respect to the environment. It also makes

752 us think that larval and nymph stages could be more tolerant in summer at low relative humidity and

753 high temperature, corroborating the great niche amplitude. However, this hypothesis still needs to be

754 validated as well as to verify the response of adults in winter.

755 The contrasting readings of solar irradiation between 'Star Grass Paddock' and 'Riparian

756 Forest' and its effect on the recorded values of relative humidity and temperature, as well as the lower

757 capture of immatures in the first habitat in the summer season (Figures 3 and 5), coincide with the

758 observations recorded in the literature. Higher relative humidity at ground level would be associated

759 with increased foliage density and decreased sunlight penetration, which could be related to the

760 preference of $A$. mixtum by areas of dense vegetation compared to open areas with short grasses

$761[83,84]$. In hydrophilic species of ixodids, such as D. variabilis o I. uriae, sub-adult stages (larvae and

762 nymphs) tend to be more prone to water stress from drying out than adults $[85,86]$. However, $A$.

763 mixtum is considered one of the most dehydration-tolerant ticks of ixodids [41], which would indicate

764 its xerophilic adaptation.

765 Therefore, its tolerance to high temperatures and low relative humidity would explain its high

766 population abundance in summer in the Matepantano farm. Where environmental conditions are

767 desiccant or limiting, the microhabitat inside the litter (p. ej., 7 to $10 \mathrm{~cm}$ below the ground) could

768 represent a refuge for ticks. This could explain why the low HR recorded in 'Star Grass Paddock', in

769 summer, coincided with a higher capture of immature A. mixtum, when compared with winter and

770 with respect to the total number of adults. The mechanisms to explain how each of the stages of $A$.

771 mixtum conserving body water should be investigated.

772 According to $[31,87]$, leaf litter is often a shelter for ticks in extreme weather conditions,

773 particularly because its structure retains moisture and provides a stable temperature for ticks. In

774 addition, potential ground hosts for tick sub-adults $[88,89]$ may find food or protection in the leaf litter.

775 The leaf litter of 'Cocoa Crop', presented an extreme humidity in winter, which could explain the

776 absence of immature A. mixtum in that habitat during collection (Figure 6). On the other hand, in 
777 'Riparian Forest' we observe a poor layer of leaf litter in summer and winter, probably due to the 778 dominant vegetation (palms) or a high rate of decomposition. This, together with the water-saturated 779 soil in winter could explain, in part, the low density of immature A. mixtum in this habitat. According 780 to [90], the transformation, fragmentation of dense canopy forest (p. ej., deciduous trees) to those 781 vegetal ecosystems with scarce canopy and less layers, it favors the flooding in winter.

782 In contrast, in summer, the low structural complexity of grassland vegetation, observed at the 783 Matepantano farm, facilitates direct solar radiation, which rapidly dries out the top layer of soil, 784 deteriorating the microclimate, increasing air temperature and decreasing relative humidity. 785 Therefore, the more developed the vegetation in the landscape (strata, diversity, coverage, height) 786 the less variation in environmental conditions and the lower the probability of extreme events of 787 temperature, humidity and light radiation, which would favor the tick population dynamics. We 788 hypothesize that the immature stages of $A$. mixtum, in the selected habitats of the Matepantano farm, 789 are less susceptible to drying out when compared to adults in the summer season.

790 This is consistent with the findings of [91], where the nymphs of $A$. sculptum in Pantanal 791 (Brazil) were found in the dry season, but not in the wet season. According to these authors, the 792 absence of larvae and nymphs in the wet season in Pantanal can be explained by a seasonal pattern, 793 which is analogous to the rainy season tick abundance in our study. [26,52] have observed the 794 synchronization of the development (behavioral diapause) of a stage of the A. cajennense s.I, so that 795 the next stage will take place under favorable weather conditions according to the season. The 796 immature-adult ratios we observed were relatively similar, depending on the time of year, to those 797 presented by [26,52].

798 Although we do not evaluate the population abundance of the A. mixtum free-living stages in 799 all months of the year at the Matepantano farm, our observations present marked contrasts in the 800 abundance of immatures between the summer and winter seasons in the selected habitats. The lower 801 abundance or absence of immature stages of $A$. mixtum in the sampling carried out in the habitats 802 'Cocoa Crop' and 'Riparian Forest' in winter could be explained by: a) the higher soil moisture, which 803 could promote a higher number of natural tick enemies [92-94] and b) the duration of the flooded 804 ground (days). [95] point out that the seasonal flooding of soils in some regions of Brazil could be 
805 unfavorable to $A$. sculptum, tick that prefers drained soils in open areas with scrub and riparian 806 forests.

807 If this occurs in the Matepantano farm, the presence of the three post-embryonic stages of

808 A. mixtum suggests two possibilities: 1) there is only one generation per year and that they are

809 successive, with a great reproductive peak between the end of the rains and the dry season.

810 However, this hypothesis has yet to be validated; 2 ) there are overlapping generations (several per

811 year), even if there is a reproductive peak generated by few females surviving the winter; also,

812 because throughout the year there could be immature stages (as observed in the two contrasting

813 periods) indicating several cohorts. This would be possible if the diapause capability of $A$. mixtum is

814 activated at times of the year when their survival is threatened. In laboratory [96] found that engorged

815 females from $A$. auricularium are resistant to water stress, when placed under immersion in distilled

816 water for up to 96 hours, but the reduced progeny and the delayed oviposition time were attributed to 817 diapause.

818 This would also help to explain how some females manage to survive harsh winters and

819 flooding to maintain population size over time at the Matepantano farm. We observed that a few

820 larvae of $A$. mixtum can survive up to one week under complete immersion in distilled water under

821 laboratory conditions (unpublished information). It has also been shown that the eggs of $A$.

822 americanum withstand underwater immersion periods of up to one week, without altering incubation

823 time or hatching success [97].

824 For all the above reasons, we hypothesize that the peak of relative abundance of the 825 immature stages of $A$. mixtum observed in summer at the Matepantano farm and, mainly, its 826 depression in winter (Figure 3), could be the result in winter of: a) the direct death of some vulnerable

827 immature stages, or b) the quiescent or diapause response of immature stages when experiencing 828 extreme conditions of prolonged flooding and high relative humidity. In the first option, the adults 829 survive the winter and lay eggs at the end of the rains, so some months later a high density of larvae 830 and nymphs will be observed in summer. In the second option, the larvae and/or nymphs would go 831 into diapause during the winter and come out the following summer. 
In the first case there would be overlap of generations with a main reproductive peak. In the

833 second case overlap of generations do not occur because of diapause. No doubt these hypotheses

834 along with the ability of $A$. mixtum to survive long periods of time in flooded areas, particularly in years

835 with La Niña phenomenon and high relative humidity, should be investigated, as well as their limits

836 of tolerance to environmental variables related to extreme events. It is likely that each stage of $A$.

837 mixtum tolerates and responds differently to abiotic variables and biotic interactions present in each

838 habitat of the Matepantano farm. We also believe that individuals from A. mixtum would have the

839 ability to select habitat, outside the host, as is the case with other tick species $[85,98]$.

840 The wide tolerance of $A$. mixtum to abiotic variables is reflected in the tick population's

841 preference for multiple changing habitats, as we observed in our research. Therefore, we recommend

842 investigating the mechanisms of habitat selection by this species, as well as the factors involved in

843 the detachment of the engorged tick from the host when it perceives a habitat that is favorable to it,

844 a process that we consider not to be random.

845 For its part, the fundamental niche of $A$. mixtum is determined by the tick's tolerance range

846 for the conditions it faces (i.e., temperature, humidity, solar irradiance), variables that define the

847 breadth of habitat it colonizes. Thus, the niche width of $A$. mixtum is the range of habitats, with their

848 range of resources, in which the growth rate of their population is positive. This niche amplitude

849 increases from the genetic variation of the individuals with respect to the tolerance of the variables in

850 the different types of habitat (e. g., differences in abundance between populations of stages observed

851 in the Matepantano farm), and where generalist species increase their fitness as an adaptive strategy

852 in unpredictable environments [99], as could be happening at the Matepantano farm or when the

853 species faces interspecific competition [11].

854 Briefly, a generalist species is actually composed of different specialist individuals, called

855 individual specialization [99]. This is an aspect we can explore further in different $A$. mixtum

856 populations, since larvae had the highest niche width in summer, while adults had it on winter in our

857 study. To understand niche width, it is necessary to investigate habitats with optimal niche, where $A$.

858 mixtum reaches the maximum rate of population growth. 
It makes sense for the tick species to have great niche amplitude since the longest period of

860 its life cycle is outside the host [100] and can occur in different types of habitats. Conversely, a tick

861 species specialized in one habitat type may be disadvantaged by habitat loss, fragmentation or

862 transformation [101]. According to the above, the fragmentation of habitats in an agroecosystem like

863 the Matepantano farm impacts the availability and diversity of habitats and hosts, and therefore the

864 abundance of ticks at different times of the year, where the areas, cover and types of vegetation use

865 to change. This fragmentation of the landscape $[101,102]$ could be beneficial in the case of $A$. mixtum

866 by offering a wide variety of environmental possibilities that favor their survival, reproduction and

867 niche breadth.

868 Additionally, a large supply of hosts in the Matepantano farm and biological corridors, 869 connecting patches of vegetation, would increase the connectivity between different habitats and

870 expand the capacity of the species to be generalist by tolerating different conditions and having a

871 wide range of resources to maintain the population and persist over time. The niche width of $A$. mixtum

872 in the Matepantano farm was elevated at both times of the year for adults, which indicates its ability

873 to resist environmental changes and to use different resources in changing or altered habitats,

874 favoring its spatial dispersion by the wide range of hosts it uses $[40,48,80,103]$. However, the

875 ecological niche of $A$. mixtum in the pre-adult stages (Figure 4) in the Matepantano farm was lower

876 in the winter versus summer season, which may suggest less tolerance for variables such as flooding

877 or less opportunity and availability to use the resources provided by the habitats.

878 This result certainly warrants further research. In summary, the three post-embryonic stages

879 of $A$. mixtum have the capacity to use many resources and tolerate a wide range of environmental

880 conditions in a highly heterogeneous agro-ecosystem in the Matepantano farm. Thus, A. mixtum

881 could present adaptations, phenotypic plasticity and behavior modification [11] according to the

882 habitat used, particularly those unstable (e. g., disturbed by humans and frequently changing, as King

883 Grass Crop and Cocoa Crop) which they use immediately in an opportunistic way, as they are easily

884 dispersed by a wide range of hosts.

885 The preference of the larvae and nymphs of $A$. mixtum by the habitats 'King Grass plantation'

886 and 'Star Grass paddock' in both seasons of the year may be related to their unstable nature due to 
anthropogenic activities such as cutting and grazing (Figure 4). For example, the habitat 'King Grass plantation', composed of non-perennial grass Pennisetum hybridum, is temporary and its use and preference by $A$. mixtum is opportunistic. Our observations coincide with the hypothesis of physiological plasticity indicated for the $A$. cajennense s.I by [100], where the survival of such ticks can be explained by a set of habitat variables, and not by strict host specificity. In contrast, the 'Riparian Forest' habitat was avoided by ticks according to the calculated use and preference rates (Figure 4 and Table 4). The explanation for this result could be related to a greater number of natural enemies; the constant export of ticks by wild animals to neighboring 895 habitats; the relative climatic stability of the habitat; some factor that exceeds the tolerance of the 896 ticks; or a system that has many natural enemies or controllers. Such hypotheses, however, must be 897 valid.

In the same way, we notice that the abundance (population size proxi variable) went from 900 of heavy rains and floods. The question remains as how to explain the persistence of $A$. mixtum in 901 the Matepantano farm, as the winter phenomenon could drastically affect the population size in the 902 following year. To solve this question, we calculated the intrinsic rate of population growth $=R\left(n_{t+1} / n_{t}\right)$, 903 that relates the population abundance $(n)$ in a time $(t+1)$ with respect to a previous time $(t)$; being $R=1$ 904 a stable population, $>1$ growing and $<1$ in decline. Thus, if we divide the total abundance values 905 quantified in winter (266) by those quantified in summer $(6,733)$ for $A$. mixtum would give us a $\mathrm{R}=$ 906 0.039, suggesting population decrease between summer and winter, for the same year. That is, a 907 population loss rate of $96.1 \%$ ( 1 - 0.039 ; or $100 \%-3.9 \%)$.

908 However, we quantified in winter 77 females, of which not all of them will manage to reach 909 engorgement during the winter, and many eggs by probability will not survive or develop into larvae. 910 Furthermore, assuming that the effective amount of larvae in the following summer is equal to the 911 already quantified summer, we would have 2,533 larvae. This means that when calculating $\mathrm{R}$ between 912 the winter and the expected summer of the following year it would give: 2,533 larvae next summer/77 913 females in winter $=32.89=R(1-32.89=31.89)$, giving a population growth of $3,189 \%(31.89 * 100 \%)$.

914 To know the net balance in the population growth between the summer of the quantified year and the 
915 summer of the following year, we multiply the values of $R$, so $R 0.039 \times 32.89=1.28(R=1-1.28=$

9160.28 or $0.28 \times 100 \%=28 \%$ ), resulting in a net population gain of $28 \%$.

917 This calculation suggests that, even with massive loss of individuals in the winter season (one

918 order of magnitude), the population would be increased by $28 \%$ the following year, explaining the

919 testimonies by the inhabitants of the Matepantano farm about the persistence of the species over

920 time (decades). This population persistance could be explained because a few engorged females are

921 enough to produce thousands of eggs and larvae to keep a positive population size. Nevertheless,

922 other possible explanation for the population to persist could be a continuous supply of individuals

923 (rescue effect) from neighbouring habitats or a source population (with positive growth), so these

924 new immigrants could be carried by host, being part of so-called source-sink population dynamics

925 [11]. This hypothesis should be further explored.

926 From the evidence collected we consider that the functional connectivity of the fragmented 927 agroecosystem landscape at the Matepantano farm, particularly between habitats of King Grass Crop'

928 with 'Cocoa Crop' and 'Riparian Forest' is made possible by the presence of small mammals

929 (marsupials, armadillos and rodents) and capybaras (Hydrochoerus hydrochaeris) at the

930 Matepantano farm (Figure 6). Thus, the dispersion of the tick in space and the connection between

931 habitats will depend on factors such as the availability of hosts; the activity and home range of the

932 host [46,104]; the time of transport on the host [105]; and the host's immune defense mechanisms.

933 According to $[40,48]$, the adult collection of $A$. mixtum in the Neotropics and Nearctics

934 indicates that adults of $A$. mixtum can feed on various domestic mammals and wild species, and

935 parasitize humans $[80,103]$. The connectivity between the studied habitats by the constant transit of

936 diverse hosts could help to colonize temporarily new or hostile, transformed or marginal habitats, as

937 well as to serve as a rescue mechanism for tick populations in unsuitable habitats, where the mortality

938 rate exceeds the birth rate [106-108]. Thus, some hosts serve as a bridge between habitats, either

939 because in such habitats those hosts find food [32,109] or refuge from potential predators [31]. In

940 turn, ticks take advantage of this dispersal mechanism even when the primary hosts are absent [36]

941 or have been anthropogenically restricted [110], seeing a possibility of expansion, as they are

942 opportunistic on modified fragmented and crop-based systems [111]. 
In our study area, the connectivity between adjacent habitats (King Grass Crop, Cocoa Crop,

944 Riparian Forest, and Star Grass Paddock) could also be given by the independent movement from

945 the host of ixodid ticks, regarding such a movement is usually limited, depending on the species,

946 habitat conditions and the need to search for a host. For example, [101] observed that non-fed larvae

947 of $I$. ricinus have a poor dispersal capacity due to their gregarious behavior, while the range of

948 movement of free living nymphs and adults of $A$. americanum, a tick that hunts its host, was between

94917 and $23 \mathrm{~m}$, where most of the adults moved less than $13 \mathrm{~m}$ [104].

$950 \quad$ For their part, the nymphs of $A$. maculatum disperse slowly $(1.27 \mathrm{~cm} /$ day $)$ and seek out their

951 host by moving very close to the ground (3.6 cm high) [112]. Although there is no data on the

952 horizontal movement of each A. mixtum stage, field experiments in Texas [41] indicated that in the

953 vertical displacement, in search of hosts, a third of the nymphs exceeded $30 \mathrm{~cm}$ from the ground and

$9543 \%$ of the adults were found between 10 and $60 \mathrm{~cm}$, with a maximum of $115 \mathrm{~cm}$, suggesting their

955 hunting strategy, to favor their dispersion and feeding. Less vertical movement has been reported in

956 the related species A. sculptum in Pantanal (Brazil) [91] with 15 to $50 \mathrm{~cm}$ of vertical climbing. We

957 need to investigate the abilities of $A$. mixtum in its different stages to move between habitats.

958 Our findings validate modeling results for A. mixtum of [43] in the Neotropics and [113] in

959 Colombia, who point out different types of vegetation cover, as well as hot and dry seasons, as

960 favorable for the presence of this tick. Because of its high thermal tolerance and niche amplitude, $A$.

961 mixtum colonizes several types of habitats in the Matepantano farm that provide diverse resources

962 and climatic conditions, which coupled with functional connectivity by the hosts, allow it to adapt and

963 survive in changing habitats. However, this characteristic of the tick represents a serious problem for

964 the human and veterinary public health systems.

965 We consider, based on the results of our study, that $A$. mixtum is more vulnerable in winter,

966 especially in the flooding season. In this regard, control measures should focus on the elimination of

967 A. mixtum female in winter and the control of larvae and nymphs in habitats changed by human

968 activity, with temporary or unstable characteristics around 'Riparian Forest', such as 'Star Grass

969 Paddock' and 'King Grass Crop'. Reducing the risk of rickettsial infection in humans should be the

970 goal of control measures on the Matepantano farm and in the Llanos Orientales region. 
971 It is recommended to monitor the populations of $A$. mixtum free-living stages in the different

972 habitats of the Matepantano farm, as well as their parasitic populations on domestic and wild animals,

973 in relation to the climate and microclimate at different times of the year. Such information will be useful

974 in determining the local distribution of $A$. mixtum and to identify those key factors that explain the

975 tolerance of the tick to extreme values of temperature and $\mathrm{RH}$, in order to plan effective and specific

976 strategies of control of its off-host stages in the region.

\section{Conclusion}

A. mixtum presented preference for diverse environments in the Matepantano farm, as well

981 as niche amplitude and tolerance to strong environmental fluctuations. All stages of $A$. mixtum use

982 the 'Riparian Forest' but do not prefer it, which is compensated by the preference of three changing

983 and transformed habitats in their surroundings. The population was more abundant in the dry season

984 (larvae and nymphs) and decreased by one order of magnitude in winter (more adults, relatively). In

985 winter, the immature stages were less abundant and could be more susceptible to the upper end of

986 humidity and flooding, so control could be more effective there.

Further research should be developed to understand the morphophysiological or behavioral

988 strategies and adaptations of $A$. mixtum to tolerate wide fluctuations and extreme changes in climate

989 and microclimate. Several variables that falling within the scope of 'functional habitat' (e. g., host

990 richness within each habitat associated to A. mixtum; host parasitic load; host biotic interactions with

991 natural enemies; and host role in landscape connectivity, maintenance and persistence of tick

992 populations) should be included in future research. Also, tick intrinsic variables, like photoperiod

993 behavior and development, might help to explain the parasitic and non-parasitic population peaks of

994 all $A$. mixtum stages in dry and wet seasons, to determine generational overlap, and to distinguish

995 strategies for survival for every developmental stage. The population control of $A$. mixtum should be

996 carried out at the time of greatest vulnerability (e. g., winter), where the population size is low, and

997 must be directed mainly towards females. 
999 Acknowledgements

We thank Sergio Andrés Viniescas Pineda and Victor Montaña, responsible for the Davis

1001 Weather Station, (Finca Matepantano, Yopal, Casanare) for sharing with us the weather data of seven

1002 consecutive years. Also, we are grateful for the immense support of Patrick Nicolás Skillings for taking

1003 and processing the images of the Matepantano farm with drone. Finally, our recognition to the

1004 undergraduate students in Veterinary Medicine of La Salle University Laura Coy and Rafael Salazar,

1005 and to the graduate students in Biology of the Pontificia Universidad Javeriana Náyade Cortés and

1006 María Fernanda Cogollos. Our special thanks to the Young Researcher Juliana Gil, sponsored by

1007 Colciencias.

1008

1009 Author contribution statement

A.A., E.B. and M.H. conceptualized the project. M.H. received research funds from the

1011 Pontificia Universidad Javeriana, Bogotá Campus. A.A., E.B. and E.F.-B. carried out the field work.

1012 A.A. conducted, analyzed and presented the statistical information of habitat use and preference in

1013 tables and figures, and structured the document with the support of E.F.-B. and E.B. A.A. and E.F.-

1014 B. wrote the manuscript. All the authors reviewed and edited the manuscript in its different sections.

1015

1016 Conflict of interest

1017 The authors declare there is no conflict of interest regarding the publication of this paper.

1018

1019 Contribution to the field statement

1020 Empirical data of high niche amplitude in an agroecosystem with fragmented habitats and

1021 availability of a variety of domestic and wild hosts represent new knowledge for the species. 


\section{Funding}

1024 This work was funded by the Convocatoria 06 of 2016 for Interdisciplinary Research Projects

1025 of the Pontificia Universidad Javeriana, Bogotá Campus, under budget code 12012150401200, to

1026 MH. E.F.-B. was financed through the postdoctoral fellowship of Colciencias, Convocatoria 784 of

10272017.

1028

1029 References

1030

1031 1. Manly BFJ, McDonald LL, Thomas DL. Resource Selection by Animals: Statistical design and analysis for field

1032 studies. 1st ed. London: Chapman \& Hall; 1993. doi:10.1007/978-94-011-1558-2

$10332 . \quad$ Montenegro-González J, Acosta A. Habitat preference of Zoantharia genera depends on host sponge morphology.

$1034 \quad$ Univ Sci. 2010;15: 110-121. doi:10.11144/javeriana.SC15-2.hpoz

1035 3. Millspaugh JJ, Rota CT, Gitzen RA, Montgomery RA, Bonnot TW, Belant JL, et al. Analysis of Resource Selection

1036

1037

1038 by Animals. 1st ed. In: Murray DL, Sandercock BK, editors. Population ecology in practice. 1st ed. Hoboken: WileyBlackwell; 2020. pp. 333-358. Available: https://www.wiley.com/en-co/Population+Ecology+in+Practice-p-

1039 4. Batzli GO, Lesieutre C. The Influence of High Quality Food on Habitat Use by Arctic Microtine Rodents. Oikos. 1991;60: 299-306. doi:10.2307/3545071

10415 5. Morris DW. Toward an ecological synthesis: A case for habitat selection. Oecologia. 2003;136: 1-13.

1042 doi:10.1007/s00442-003-1241-4

1043 6. Lele SR, Merrill EH, Keim J, Boyce MS. Selection, use, choice and occupancy: Clarifying concepts in resource 1044 selection studies. J Anim Ecol. 2013;82: 1183-1191. doi:10.1111/1365-2656.12141

1045 7. Northrup JM, Hooten MB, Anderson CRJ, Wittemyer G. selection functions under a use - availability design R 1046 eports R eports. Ecol Soc Am. 2013;94: 1456-1463. doi:10.1890/12-1688.1

1047 8. Bernal-Sotelo K, Acosta A, Cortés J. Decadal change in the population of Dendrogyra cylindrus (Scleractinia:

1048 Meandrinidae) in old providence and St. Catalina Islands, Colombian Caribbean. Front Mar Sci. 2019;5: 1-13.

1049 doi:10.3389/fmars.2018.00513

1050 9. Krausman PR. Some Basic Principles of Habitat Use. In: Launchbaugh, K.L., Mosley, J.C., Sanders KD, editor. 1051 Grazing Behavior of Livestock and Wildlife. Idaho: University of Idaho Forest, Wildlife and Range Experiment Station; 1999. pp. 85-90. Available: http://www.lib.uidaho.edu/special-collections/

1053 10. Montenegro González JA, Acosta Moreno LA. Programa innovador para evaluar uso y preferencia de hábitat. Univ 
bioRxiv preprint doi: https://doi.org/10.1101/2020.12.23.424125; this version posted December 23,2020 . The copyright holder for this preprint (which was not certified by peer review) is the author/funder, who has granted bioRxiv a license to display the preprint in perpetuity. It is made available under aCC-BY 4.0 International license.

1054

105511.

1056

1057

1058

1059

1060

1061

1062

1063

1064

1065

1066

$1067 \quad 16$

1068

1069

1070

1071

1072

1073

107420

1075

1076

1077

1078

1079

1080

1081

23.

1082

1083

24.

1084

1085

25.

1086

1087

26.

sci. 2008;13: 208-217. Available: http://www.scielo.org.co/pdf/unsc/v13n2/v13n2a11.pdf

Polechová J, Storch D. Ecological niche. 2nd ed. In: Fath B, editor. Encyclopedia of Ecology. 2nd ed. Oxford: Elsevier Inc.; 2019. pp. 72-80. doi:10.1016/B978-0-12-409548-9.11113-3

12. Whittaker RH, Gaugh HG. Evalution of Ordination Techniques. 1st ed. In: Whittaker RH, editor. Ordination of Plant Communities. 1st ed. The Hague: Dr. W. Junk Publishers; 1978. pp. 277-336. doi:10.1007/978-94-009-7989-5

3. Klinka K, Krajina VJ, Ceska A, Scagelis AM. Indicator Plants of Coastal British Columbia. 1st ed. Vancouver: University of British Columbia Press; 1989. Available: https://www.ubcpress.ca/indicator-plants-of-coastal-britishcolumbia

14. Gliessman SR. Agroecology: The Ecology of Sustainable Food Systems. 3rd ed. Boca Raton: CRC Press; 2015. Available: https://www.routledge.com/Agroecology-The-Ecology-of-Sustainable-Food-Systems-Third-Edition3rd/Gliessman/p/book/9781439895610

15. Martínez-Meyer E, Díaz-Porras D, Peterson AT, Yáñez-Arenas C. Ecological niche structure and rangewide abundance patterns of species. Biol Lett. 2012;9: 1-5. doi:10.1098/rsbl.2012.0637

Gutiérrez JA, Krenz JD, Ibargüengoytía NR. Effect of altitude on thermal responses of Liolaemus pictus argentinus in Argentina. J Therm Biol. 2010;35: 332-337. doi:10.1016/j.jtherbio.2010.07.001

17. Petitpierre B, Kueffer C, Broennimann O, Randin C, Daehler C, Guisan A. Climatic niche shifts are rare among terrestrial plant invaders. Science (80- ). 2012;335: 1344-1348. doi:10.1126/science.1215933

18. Pulliam R. Sources, sinks, and population regulation. Am Nat. 1988;132: 652-661.

19. Ruiz-Sanchez E, Rodriguez-Gomez F, Sosa V. Refugia and geographic barriers of populations of the desert poppy, Hunnemannia fumariifolia (Papaveraceae). Org Divers Evol. 2012;12: 133-143. doi:10.1007/s13127-012-0089-z

20. Sinervo B, Méndez-de-la-Cruz F, Miles DB, Heulin B, Bastiaans E, Cruz MVS, et al. Erosion of lizard diversity by climate change and altered thermal niches. Science (80- ). 2010;328: 894-899. doi:10.1126/science.1184695

21. Labruna MB. Ecology of spotted fever rickettsioses in Latin America. Acta Med Costarric. 2013;Suppl 1: 61-62. Available: https://www.scielo.sa.cr/scielo.php?script=sci_serial\&pid=0001-6002

22. Ogrzewalska M, Saraiva DG, Moraes-Filho J, Martins TF, Costa FB, Pinter A, et al. Epidemiology of Brazilian spotted fever in the Atlantic Forest, state of São Paulo, Brazil. Parasitology. 2012;139: 1283-1300. doi:10.1017/S0031182012000546

Labruna MB, Kasai N, Ferreira F, Faccini JLH, Gennari SM. Seasonal dynamics of ticks (Acari: Ixodidae) on horses in the state of São Paulo, Brazil. Vet Parasitol. 2002;105: 65-77. doi:10.1016/S0304-4017(01)00649-5

Oliveira PR, Borges LMF, Leite RC, Freitas CMV. Seasonal dynamics of the Cayenne tick, Amblyomma cajennense on horses in Brazil. Med Vet Entomol. 2003;17: 412-416. doi:10.1111/j.1365-2915.2003.00459.x

Pinter A, Dias RA, Gennari SM, Labruna MB. Study of the Seasonal Dynamics, Life Cycle, and Host Specificity of Amblyomma aureolatum (Acari: Ixodidae) . J Med Entomol. 2004;41: 324-332. doi:10.1603/0022-2585-41.3.324

Labruna MB, Terassini FA, Camargo LMA. Notes on Population Dynamics of Amblyomma Ticks (Acari: Ixodidae) in Brazil. J Parasitol. 2009;95: 1016-1018. doi:10.1645/ge-1878.1 
bioRxiv preprint doi: https://doi.org/10.1101/2020.12.23.424125; this version posted December 23,2020 . The copyright holder for this preprint (which was not certified by peer review) is the author/funder, who has granted bioRxiv a license to display the preprint in perpetuity. It is made available under aCC-BY 4.0 International license.

1089 27. Nava S, Mangold AJ, Mastropaolo M, Venzal JM, Fracassi N, Guglielmone AA. Seasonal dynamics and hosts of $1090 \quad$ Amblyomma triste (Acari: Ixodidae) in Argentina. Vet Parasitol. 2011;181: 301-308. doi:10.1016/j.vetpar.2011.03.054

1092

28. Ludwig A, Ginsberg HS, Hickling GJ, Ogden NH. A dynamic population model to investigate effects of climate and climate-independent factors on the lifecycle of Amblyomma americanum (Acari: Ixodidae). J Med Entomol. 2016;53: 99-115. doi:10.1093/jme/tjv150

1095

29. Tarragona EL, Sebastian PS, Saracho Bottero MN, Martinez El, Debárbora VN, Mangold AJ, et al. Seasonal dynamics, geographical range size, hosts, genetic diversity and phylogeography of Amblyomma sculptum in Argentina. Ticks Tick Borne Dis. 2018;9: 1264-1274. doi:10.1016/j.ttbdis.2018.04.009 Adalsteinsson SA, D’Amico V, Shriver WG, Brisson D, Buler JJ. Scale- dependent effects of nonnative plant invasion on host- seeking tick abundance. Ecosphere. 2016;7: e01317. doi:10.1002/ecs2.1317 Aléssio FM, Dantas-Torres F, Siqueira DB, Lizée MH, Marvulo MFV, Martins TF, et al. Ecological implications on the aggregation of Amblyomma fuscum (Acari: Ixodidae) on Thrichomys laurentius (Rodentia: Echimyidae), in northeastern Brazil. Exp Appl Acarol. 2012;57: 83-90. doi:10.1007/s10493-012-9531-3 Allan BF, Dutra HP, Goessling LS, Barnett K, Chasea JM, Marquis RJ, et al. Invasive honeysuckle eradication reduces tick-borne disease risk by altering host dynamics. Proc Natl Acad Sci U S A. 2010;107: 18523-18527. doi:10.1073/pnas.1008362107

1112 35. Ehrmann S, Ruyts SC, Scherer-Lorenzen M, Bauhus J, Brunet J, Cousins SAO, et al. Habitat properties are key drivers of Borrelia burgdorferi (s.I.) prevalence in Ixodes ricinus populations of deciduous forest fragments.

1115 36. Eisen L, Eisen RJ, Lane RS. Geographical Distribution Patterns and Habitat Suitability Models for Presence of 1116 Host-Seeking Ixodid Ticks in Dense Woodlands of Mendocino County, California. J Med Entomol. 2006;43: 4151117 427. doi:10.1603/0022-2585(2006)043[0415:gdpahs]2.0.co;2

1118 37. Ennen JR, Qualls CP. Distribution and Habitat Utilization of the Gopher Tortoise Tick (Amblyomma tuberculatum) in 1119 Southern Mississippi. J Parasitol. 2011;97: 202-206. doi:10.1645/ge-2599.1

1120 38. Phillips PL, Welch JB, Kramer M. Development of a Spatially Targeted Field Sampling Technique for the Southern Cattle Tick, Rhipicephalus microplus , by Mapping Whitetailed Deer, Odocoileus virginianus , Habitat in South Texas. J Insect Sci. 2014;14: 1-21. doi:10.1673/031.014.88 
variables are not enough when predicting tick populations in the Southeastern United States. PLoS One. 2015;10:

1126 40. Coronel-Benedett KC, Ojeda-Robertos NF, González-Garduño R, Ibañez FM, Rodríguez-Vivas RI. Prevalence, 1127 intensity and population dynamics of hard ticks (Acari: Ixodidae) on sheep in the humid tropics of Mexico. Exp Appl

1128 Acarol. 2018;74: 99-105. doi:10.1007/s10493-017-0195-x

1129 41. Beck DL, Orozco JP. Diurnal questing behavior of Amblyomma mixtum (Acari: Ixodidae). Exp Appl Acarol. 2015;66:

1130 613-621. doi:10.1007/s10493-015-9928-x

1131 42. Pascoe EL, Marcantonio M, Caminade C, Foley JE. Modeling Potential Habitat for Amblyomma Tick Species in

1132 California. Insects. 2019;10: 1-19. doi:10.3390/insects10070201

1133 43. Estrada-Peña A, Tarragona EL, Vesco U, Meneghi D de, Mastropaolo M, Mangold AJ, et al. Divergent

1134 environmental preferences and areas of sympatry of tick species in the Amblyomma cajennense complex

1135 (Ixodidae). Int J Parasitol. 2014;44: 1081-1089. doi:10.1016/j.ijpara.2014.08.007

1136 44. Hartemink N, Takken W. Trends in tick population dynamics and pathogen transmission in emerging tick-borne

1137 pathogens in Europe: an introduction. Exp Appl Acarol. 2016;68: 269-278. doi:10.1007/s10493-015-0003-4

1138 45. Basille M, Calenge C, Marboutin É, Andersen R, Gaillard JM. Assessing habitat selection using multivariate statistics: Some refinements of the ecological-niche factor analysis. Ecol Modell. 2008;211: 233-240. doi:10.1016/j.ecolmodel.2007.09.006

46. Norman RA, Worton AJ, Gilbert L. Past and future perspectives on mathematical models of tick-borne pathogens. Parasitology. 2016;143: 850-859. doi:10.1017/S0031182015001523 rickettsioses around the world: A geographic approach. Clin Microbiol Rev. 2013;26: 657-702. doi:10.1128/CMR.00032-13

Nava S, Beati L, Labruna MB, Cáceres AG, Mangold AJ, Guglielmone AA. Reassessment of the taxonomic status of Amblyomma cajennense (Fabricius, 1787) with the description of three new species, Amblyomma tonelliae $\mathrm{n}$. sp., Amblyomma interandinum n. sp. and Amblyomma patinoi n. sp., and reinstatement of Amblyomma mixtum

1150 49. Faccini-Martínez ÁA, Costa FB, Hayama-Ueno TE, Ramírez-Hernández A, Cortés-Vecino JA, Labruna MB, et al. Rickettsia rickettsii in amblyomma patinoi ticks, colombia. Emerg Infect Dis. 2015;21: 537-539.

1153 50. Peña-R. Y, Olaya-M. LA, Hidalgo M. ESTUDIO SEROLÓGICO Y ENTOMOLÓGICO DE RICKETTSIOSIS EN DOS

1157 51. Rivera-Páez FA, Martins TF, Ossa-López PA, Sampieri BR, Camargo-Mathias MI. Detection of Rickettsia spp. in 
1159

1160

1161

1162

1163

1164

1165

1166

1167

1168

1169

1170

1171

1172

1173

1174

1175

1176

1177

1178

1179

1180

118159

118260

1183

1184

1185

1186

1187

1188

1189

1190

1191

1192

1193

doi:10.1016/j.ttbdis.2018.03.006

52. Oliveira PR, Borges LMF, Lopes CML, Leite RC. Population dynamics of the free-living stages of Amblyomma cajennense (Fabricius, 1787) (Acari: Ixodidae) on pastures of Pedro Leopoldo, Minas Gerais State, Brazil. Vet Parasitol. 2000;92: 295-301. doi:10.1016/S0304-4017(00)00322-8

53. Venzal JM, Estrada-Peña A, Castro O, de Souza CG, Félix ML, Nava S, et al. Amblyomma triste Koch, 1844 (Acari: Ixodidae): Hosts and seasonality of the vector of Rickettsia parkeri in Uruguay. Vet Parasitol. 2008;155: 104-109. doi:10.1016/j.vetpar.2008.04.017

54. Álvarez V, Bonilla R. Adultos y ninfas de la garrapata Amblyomma cajennense Fabricius (Acari: Ixodidae) en equinos y bovinos. Agron Costarric. 2007;31: 61-69. Available: www.mag.go.cr/rev agr/inicio.htm

55. Keirans JE. Order Ixodida. 3rd ed. In: Krantz GW, Walter DE, editors. A manual of acarology. 3rd ed. Lubbock: Texas Tech University Press; 2009. pp. 111-123.

56. Jones EK, Clifford CM, Keirans JE, Kohls GM. The ticks of Venezuela (Acarina: Ixodoidea) with a key to the species of Amblyomma in the Western hemisphere. Brigham Young Univ Sci Bull. 1972;17: 11-18. Available: https://scholarsarchive.byu.edu/byuscib/vol17/iss4/1.

57. Onofrio VC, Venzal JM, Pinter A, Szabó MPJ. Família Ixodidae: características gerais, comentarios e chave para gêneros. 1st ed. In: Barros-Battesti DM, Arzua M, Bechara GH, editors. Carrapatos de importância medicoveterinária da região tropical: um guia ilustrado para identificação de especies. 1st ed. São Paulo: Vox/ICTTD3/Butantan; 2006. p. 223.

58. Onofrio VC, Labruna MB, Pinter A, Giacomin FG, Barros-Battesti DM. Comentários e chaves para as espécies do gênero Amblyomma. 1st ed. In: Barros-Battesti DM, Arzua M, Bechara GH, editors. Carrapatos de importância medico-veterinária da região tropical: um guia ilustrado para identificação de especies. 1st ed. São Paulo: Vox/ICTTD-3/Butantan; 2006. p. 223.

59. Volzit OV. A review of Neotropical Amblyomma species (Acari: Ixodidae). Acarina. 2007;15: 3-134.

60. Aebischer NJ, Robertson PA, Kenward RE. Compositional Analysis of Habitat Use From Animal Radio-Tracking Data. Ecology. 1993;74: 1313-1325. doi:10.2307/1940062

61. Montenegro JA, Acosta A, Reimer JD. Havistat@ v2.2: Application to estimate preference for habitat and resources. Univ Sci. 2014;19: 333-337. doi:10.11144/Javeriana.SC19-3.haea

62. Johnson DH. The Comparison of Usage and Availability Measurements for Evaluating Resource Preference. Ecology. 1980;61: 65-71. doi:10.2307/1937156

63. Both C, Visser ME. Breeding territory size affects fitness: An experimental study on competition at the individual level. J Anim Ecol. 2000;69: 1021-1030. doi:10.1046/j.1365-2656.2000.00458.x

64. Duncan P. Determinants of the Use of Habitat by Horses in a Mediterranean Wetland. J Anim Ecol. 1983;52: 93109. doi: $10.2307 / 4590$

65. Ivlev VS. Experimental ecology of the feeding of fishes. [Translated from the Russian by Douglas Scott]. 1st ed. New Haven: Yale University Press; 1961. Available: https://lccn.loc.gov/61006667 
1194 66. Bailey BJR. Large sample simultaneous confidence intervals for the multinomial probabilities based on

1195 transformations of the cell frequencies. Technometrics. 1980;22: 583-589. doi:10.1080/00401706.1980.10486208

1196 67. Manly BFJ, Miller P, Cook LM. Analysis of a selective predation experiment. Am Nat. 1972;106: 719-736.

1197 68. Chesson J. Measuring Preference in Selective Predation. Ecology. 1978;59: 211-215. doi:10.2307/1936364

1198 69. Baltz D. Autoecology. 1st ed. In: Schreck CB, Moyle PB, editors. Methods for Fish Biology. 1st ed. Bethesda:

1199 American Fisheries Society; 1990. pp. 585-600. doi:10.1016/0165-7836(93)90099-s

1200 70. Jacobs J. Quantitative measurement of food selection: a modification of the Forage Ratio and Ivlev's Electivity

$1201 \quad$ Index. Oecologia. 1974;14: 413-417.

1202 71. Cherry S. A Comparison of Confidence Interval Methods for Habitat Use-Availability Studies. J Wildl Manage.

1203 1996;60: 653-658. doi:10.2307/3802084

1204 72. Colwell RK, Futuyma DJ. On the Measurement of Niche Breadth and Overlap. Ecology. 1971;52: 567-576.

1205 doi: $10.2307 / 1934144$

1206 73. Levins R. Evolution in Changing Environments: some theoretical explanations. 1st ed. New Jersey: Princeton

$1207 \quad$ University Press; 1968. doi:10.2307/j.ctvx5wbbh

1208 74. Hurlbert SH. The Measurement of Niche Overlap and Some Relatives. Ecology. 2017;59: 67-77.

1209 doi: $10.2307 / 1936632$

$121075 . \quad$ Huang LQ, Guo XG, Wu D, Zhou DH. Distribution and ecological niches of gamasid mites (Acari: Mesostigmata) on small mammals in Southwest China. Psyche (London). 2010; Article ID 934508, 12 pages.

doi:10.1155/2010/934508

1213 76. Yu SL, Lee TW. Habitat preference of the stream fish, Sinogastromyzon puliensis (Homalopteridae). Zool Stud. $1214 \quad 2002 ; 41: 183-187$.

1215 77. Dardanelli S, Fandiño B, Calamari NC, Canavelli SB, Zaccagnini ME. ¿Eligen las palomas y cotorras los lotes de soja (Glycine max) en emergencia? Un caso de estudio en agroecosistemas de Entre Ríos, Argentina. Rev Mex Biodivers. 2016;87: 1308-1314. doi:10.1016/j.rmb.2016.09.006

1218 78. Pozo-Zamora GM, Aguirre J, Brito J. Dieta del cernícalo americano (Falco sparverius Linnaeus, 1758) en dos 1219 localidades del valle interandino del norte de Ecuador. Rev Peru Biol. 2017;24: 145-150.

1220 doi:10.15381/rpb.v24i2.12305

1221 79. Bernal-Sotelo K. Cambio Espacio-Temporal (2000-2012) del Complejo Arrecifal de las Islas de Providencia y Santa 1222 Catalina, Caribe colombiano. Universidad de Costa Rica, San Pedro. 2015.

1223 80. Bermúdez SE, Castro AM, Trejos D, García GG, Gabster A, Miranda RJ, et al. Distribution of Spotted Fever Group 1224 Rickettsiae in Hard Ticks (Ixodida: Ixodidae) from Panamanian Urban and Rural Environments (2007-2013).

1225 Ecohealth. 2016;13: 274-284. doi:10.1007/s10393-016-1118-8

1226 81. Strey OF, Teel PD, Longnecker MT, Needham GR. Survival and Water-Balance Characteristics of Unfed Adult 1227 Amblyomma cajennense (Acari: Ixodidae). J Med Entomol. 1996;33: 63-73. doi:10.1093/jmedent/33.1.63

1228 82. Needham GR, Teel PD. Off-Host Physiological Ecology of Ixodid Ticks. Annual Review of Entomology. Annu Rev 
1229

1230

1231

1232

1233

1234

1235

1236

1237

1238

1239

1240

1241

1242

1243

1244

1245

1246

1247

1248

1249

1250

1251

1252

1253

1254

1255

1256

1257

1258

1259

1260

1261

1262

1263
Entomol. 1991;36: 659-681.

83. Beck DL, Zavala J, Montalvo EO, Quintana FG. Meteorological indicators for Amblyomma cajennense and population dynamics in the Tamaulipan Biotic Province in Texas. J Vector Ecol. 2011;36: 135-146.

doi:10.1111/j.1948-7134.2011.00150.x

84. Smith MW. Some aspects of the ecology and lifecycle of amblyomma cajennense(fabricius 1787) in trinidad and their influence on tick control measures. Ann Trop Med Parasitol. 1975;69: 121-129.

doi:10.1080/00034983.1975.11686991

85. Benoit JB, Yoder JA, Lopez-Martinez G, Elnitsky MA, Lee RE, Denlinger DL. Habitat requirements of the seabird tick, Ixodes uriae (Acari: Ixodidae), from the Antarctic Peninsula in relation to water balance characteristics of eggs, nonfed and engorged stages. J Comp Physiol B Biochem Syst Environ Physiol. 2007;177: 205-215. doi:10.1007/s00360-006-0122-7

86. Yoder JA, Rosendale AJ, Benoit JB. Short day-triggered quiescence promotes water conservation in the American dog tick, Dermacentor variabilis. J Comp Physiol B Biochem Syst Environ Physiol. 2016;186: 287-296.

doi:10.1007/s00360-015-0955-z

87. Holmes CJ, Dobrotka CJ, Farrow DW, Rosendale AJ, Benoit JB, Pekins PJ, et al. Low and high thermal tolerance characteristics for unfed larvae of the winter tick Dermacentor albipictus (Acari: Ixodidae) with special reference to moose. Ticks Tick Borne Dis. 2018;9: 25-30. doi:10.1016/j.ttbdis.2017.10.013

88. Nava S, Mangold AJ, Guglielmone AA. The natural hosts of larvae and nymphs of Amblyomma tigrinum Koch, 1844 (Acari: Ixodidae). Vet Parasitol. 2006;140: 124-132. doi:10.1016/j.vetpar.2006.03.009

89. Nava S, Mangold AJ, Guglielmone AA. The natural hosts for larvae and nymphs of Amblyomma neumanni and Amblyomma parvum (Acari: Ixodidae). Exp Appl Acarol. 2006;40: 123-131. doi:10.1007/s10493-006-9026-1

90. Von Arx G, Graf Pannatier E, Thimonier A, Rebetez M. Microclimate in forests with varying leaf area index and soil moisture: Potential implications for seedling establishment in a changing climate. J Ecol. 2013;101: 1201-1213. doi:10.1111/1365-2745.12121

91. Ramos V do N, Osava CF, Piovezan U, Szabó MPJ. Ambush behavior of the tick Amblyomma sculptum (Amblyomma cajennense complex) (Acari: Ixodidae) in the Brazilian Pantanal. Ticks Tick Borne Dis. 2017;8: 506510. doi:10.1016/j.ttbdis.2017.02.011

92. Alekseev E, Glazer I, Samish M. Effect of soil texture and moisture on the activity of entomopathogenic nematodes against female Boophilus annulatus ticks. BioControl. 2006;51: 507-518. doi:10.1007/s10526-005-2935-9

93. Yoder JA, Benoit JB, Denlinger DL, Tank JL, Zettler LW. An endosymbiotic conidial fungus, Scopulariopsis brevicaulis, protects the American dog tick, Dermacentor variabilis, from desiccation imposed by an entomopathogenic fungus. J Invertebr Pathol. 2008;97: 119-127. doi:10.1016/j.jip.2007.07.011

94. Burtis JC, Ostfeld RS, Yavitt JB, Fahey TJ. The relationship between soil arthropods and the overwinter survival of Ixodes scapularis (Acari: Ixodidae) under manipulated snow cover. J Med Entomol. 2016;53: 225-229.

doi:10.1093/jme/tjv151 
1264 95. Luz HR, Ramírez-hernández A, Benatti HR, Ramirez DG, Szabó MPJ, Labruna MB. Comparative survival of the engorged stages of Amblyomma dubitatum and Amblyomma sculptum in the laboratory: Implications for Brazilian spotted fever epidemiology. Ticks Tick Borne Dis. 2020;11: 101360. doi:10.1016/j.ttbdis.2019.101360

$1267 \quad 96$ Sá-Hungaro IJB De, Raia VDA, Pinheiro C. Amblyomma auricularium (Acari: Ixodidae): underwater survival of the non-parasitic phase of feeding females. Brazilian J Vet Parasitol. 2014;23: 387-392.

1269

97. Yoder JA, Rausch BA, Hedges BZ, Stueber SE, Jajack AJ, Benoit JB. The effects of water exposure, soil conditions, and fungus exposure on hatching of the larval lone star tick, Amblyomma americanum (Acari: Ixodidae). Int J Acarol. 2012;38: 344-352. doi:10.1080/01647954.2011.641031

1272 98. Matuschka FR, Richter D, Spielman A. Differential detachment from resting hosts of replete larval and nymphal Ixodes ticks. J Parasitol. 1991;77: 341-345. doi:10.2307/3283116

99. Navarro-López J, Vergara P, Fargallo JA. Trophic niche width, offspring condition and immunity in a raptor species. Oecologia. 2014;174: 1215-1224. doi:10.1007/s00442-013-2855-9 Nava S, Guglielmone AA. A meta-analysis of host specificity in Neotropical hard ticks (Acari: Ixodidae). Bull Entomol Res. 2013;103: 216-224. doi:10.1017/S0007485312000557

101. Perez G, Bastian S, Agoulon A, Bouju A, Durand A, Faille F, et al. Effect of landscape features on the relationship between Ixodes ricinus ticks and their small mammal hosts. Parasites and Vectors. 2016;9: 1-18. doi:10.1186/s13071-016-1296-9

102. Linske MA, Williams SC, Stafford KC, Ortega IM. Ixodes scapularis (Acari: Ixodidae) Reservoir Host Diversity and Abundance Impacts on Dilution of Borrelia burgdorferi (Spirochaetales: Spirochaetaceae) in Residential and Woodland Habitats in Connecticut, United States. J Med Entomol. 2018;55: 681-690. doi:10.1093/jme/tjx237 Chitimia-Dobler L, Schaper S, Mansfeld P, Gonschorrek J, Bröker M, Nava S. Detection of Amblyomma mixtum (Acari: Ixodidae) in Germany on a Human Traveler Returning From Cuba. J Med Entomol. 2020;57: 962-964. doi:10.1093/jme/tjz225

104. Koch KR, Burg JG. Relative abundance and survival of the tick Amblyomma americanum collected from sunlit and

1289 105. Rynkiewicz EC, Clay K. Tick community composition in Midwestern US habitats in relation to sampling method and 1290 environmental conditions. Exp Appl Acarol. 2014;64: 109-119. doi:10.1007/s10493-014-9798-7

1291 106. Patrick CD, Hair JA. White-Tailed Deer Utilization of Three Different Habitats and Its Influence on Lone Star Tick Populations. J Parasitol. 1978;64: 1100. doi:10.2307/3279735

1293 107. Lindsay LR, Mathison SW, Barker IK, McEwen SA, Gillespie TJ, Surgeoner GA. Microclimate and habitat in relation 1294 to Ixodes scapularis (Acari: Ixodidae) populations on Long Point, Ontario, Canada. J Med Entomol. 1999;36: 255262. doi:10.1093/jmedent/36.3.255

1296 108. Willis D, Carter R, Murdock C, Blair B. Relationship between habitat type, fire frequency, and Amblyomma americanum populations in east-central Alabama. J Vector Ecol. 2012;37: 373-381.

1298 109. Boyard C, Barnouin J, Gasqui P, Vourc'h G. Local environmental factors characterizing Ixodes ricinus nymph 
abundance in grazed permanent pastures for cattle. Parasitology. 2007;134: 987-994. doi:10.1017/S0031182007002351

110. Cançado PHD, Piranda EM, Mourão GM, Faccini JLH. Spatial distribution and impact of cattle-raising on ticks in the Pantanal region of Brazil by using the CO2 tick trap. Parasitol Res. 2008;103: 371-377. doi:10.1007/s00436-0080982-8

111. Szabó MPJ, Pinter A, Labruna MB. Ecology, biology and distribution of spotted-fever tick vectors in Brazil. Front Cell Infect Microbiol. 2013;3: 27. doi:10.3389/fcimb.2013.00027 maculatum koch (Acari: Ixodidae). J Parasitol. 2016;102: 481-483. doi:10.1645/15-909

\section{Supporting information captions}

1313 S1 Appendix. Procedure used for drone orthomosaic mapping.

1314 S2 Appendix. Procedure for vegetation cover estimation within each habitat.

1315 S3 Appendix. Description of the making process for the ice traps and for the white flannelettes to collect free-living 1316 ticks on the field.

1317 S1 Table. Codification for every ice trap $(\mathrm{N}=24)$ with effective tick collection in summer, including sample code, 1318 habitat and GPS coordinates.

1319 S2 Table. Codification for every transect $(\mathbf{N}=\mathbf{2 2})$ with effective tick collection in summer, including sample code, 1320 habitat and GPS coordinates.

1321 S3 Table. Codification for every ice trap $(\mathrm{N}=31)$ with effective tick collection in winter, including sample code, habitat 1322 and GPS coordinates.

1323 S4 Table. Codification for every transect $(\mathrm{N}=\mathbf{2 2})$ with effective tick collection in winter, including sample code, habitat 1324 and GPS coordinates.

1325 Table 8. Abiotic variables recorded for Amblyomma mixtum in literature. 


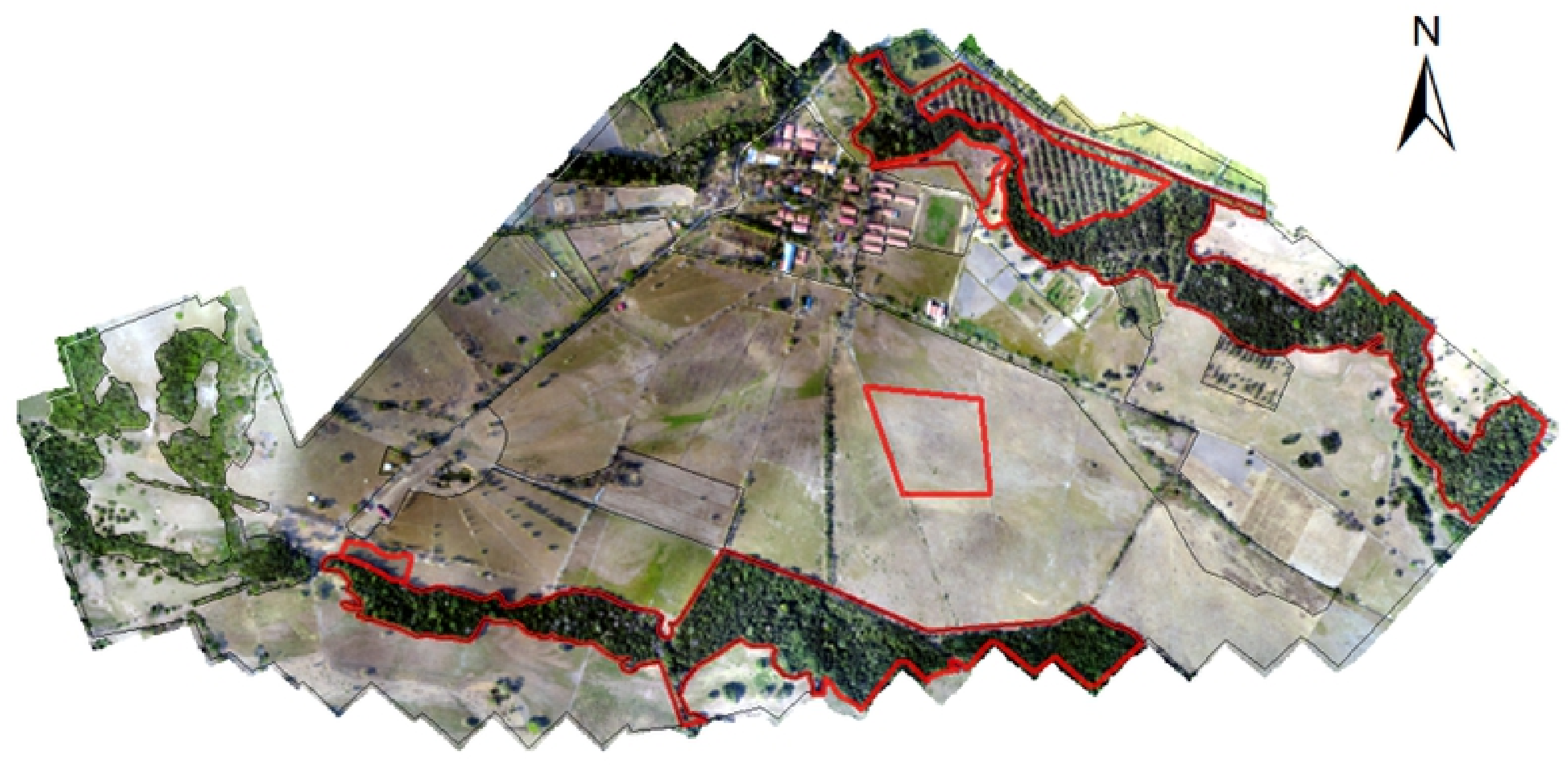

$0 \quad 125250$

500

$750 \quad 1,000$

Figure 1 


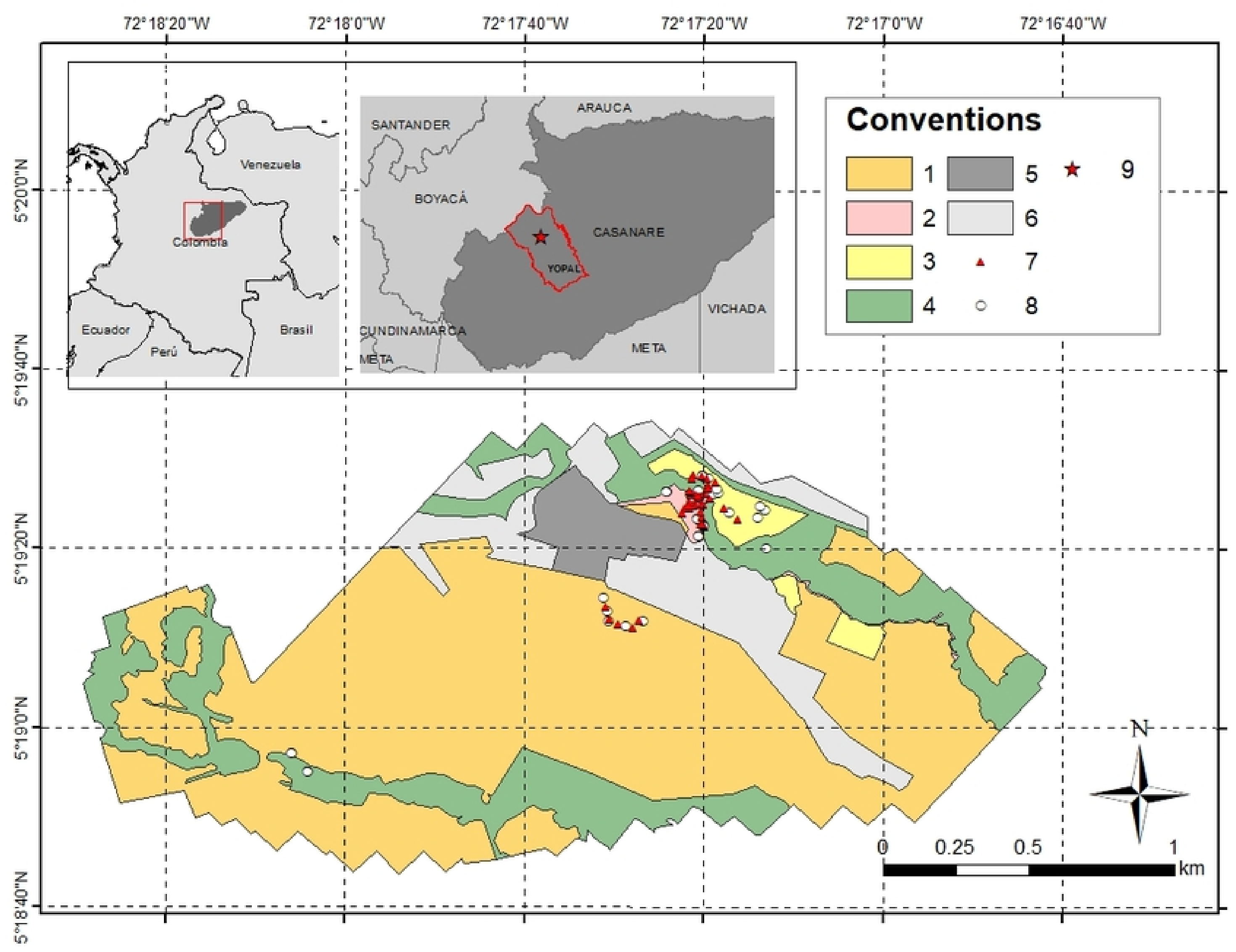

Figure 2 
(A)

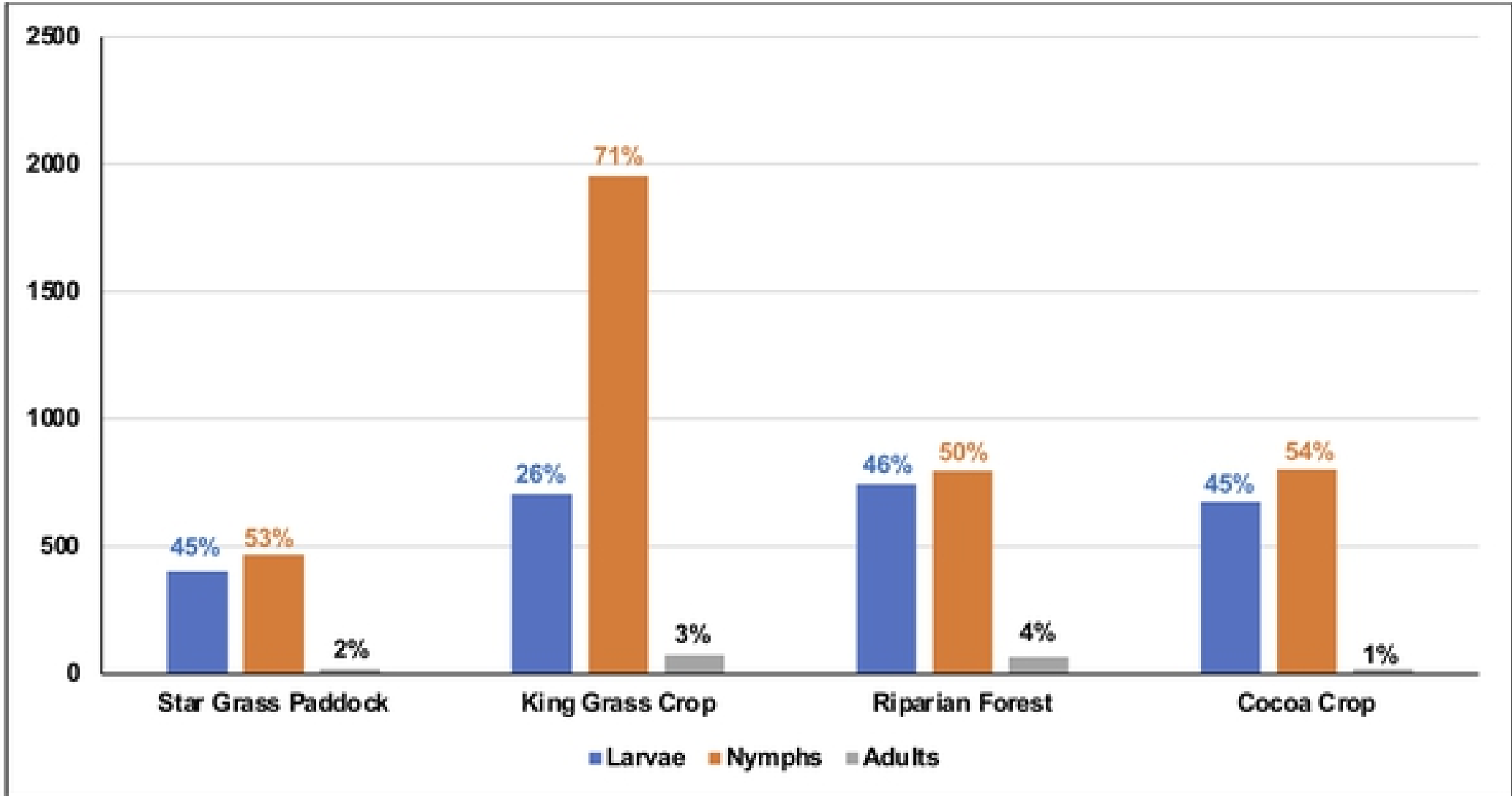

(B)

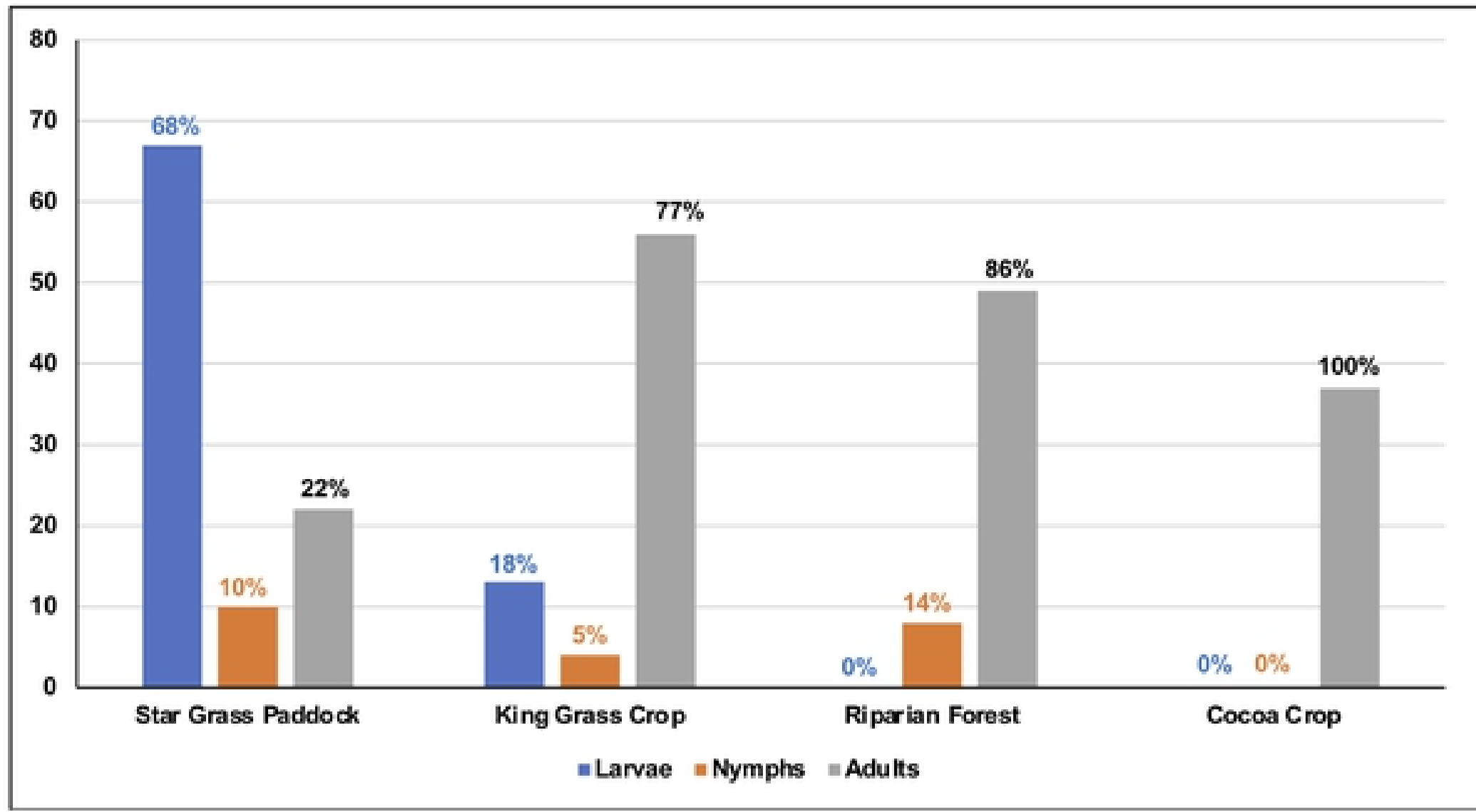

Figure 3 


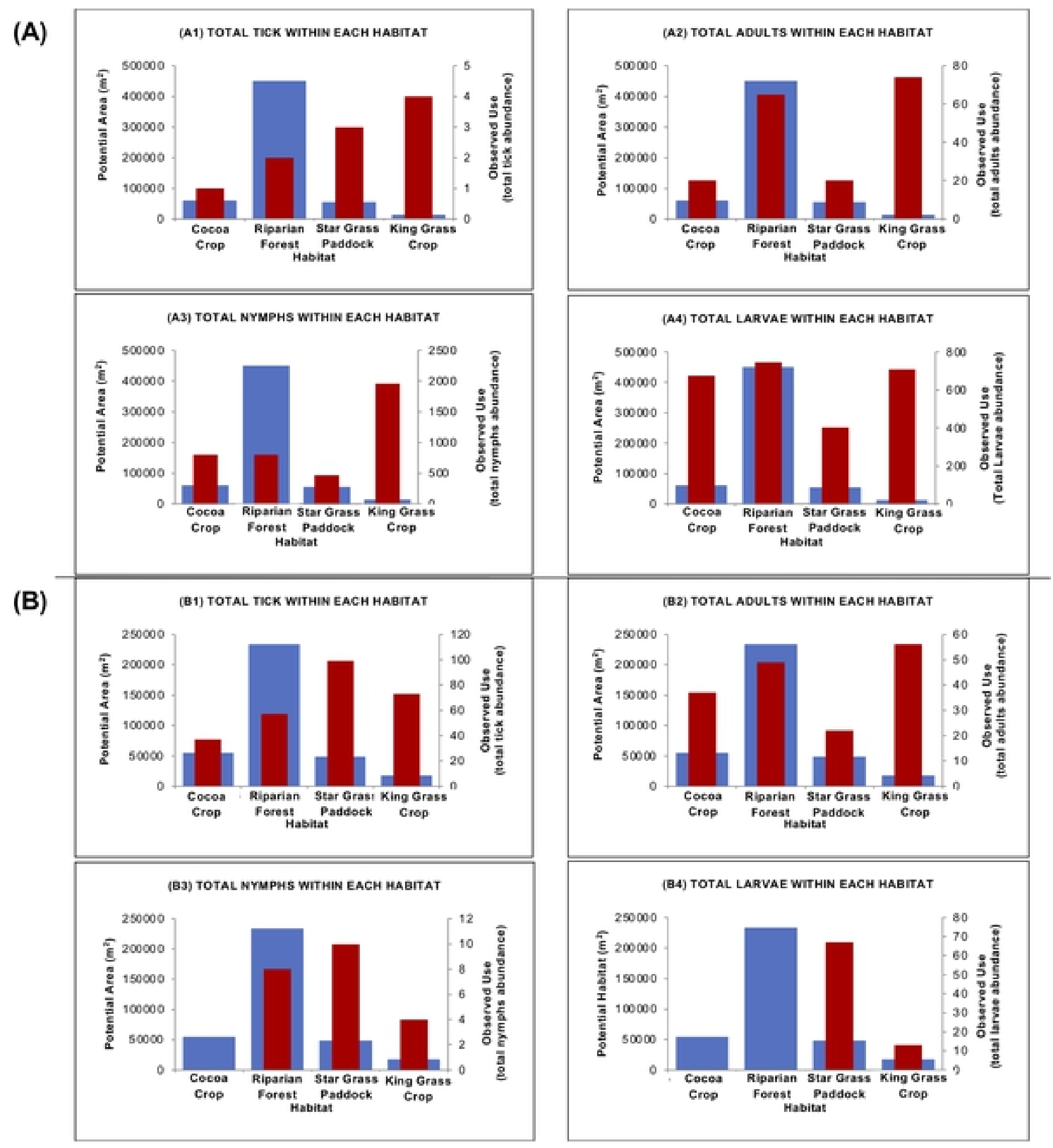

Figure 4 
A. 'Cocoa Crop' habitat on 08.Feb.2019 at $30 \mathrm{~cm}$ above the ground.
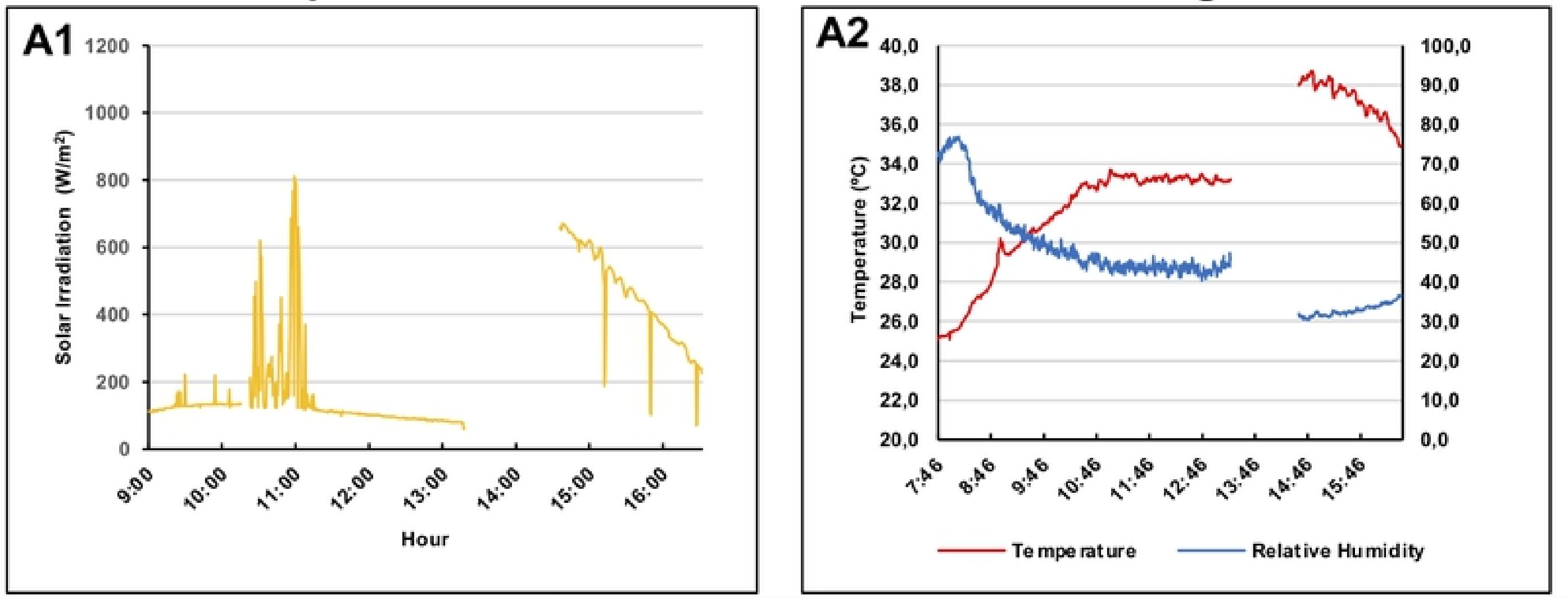

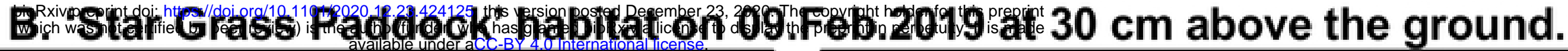
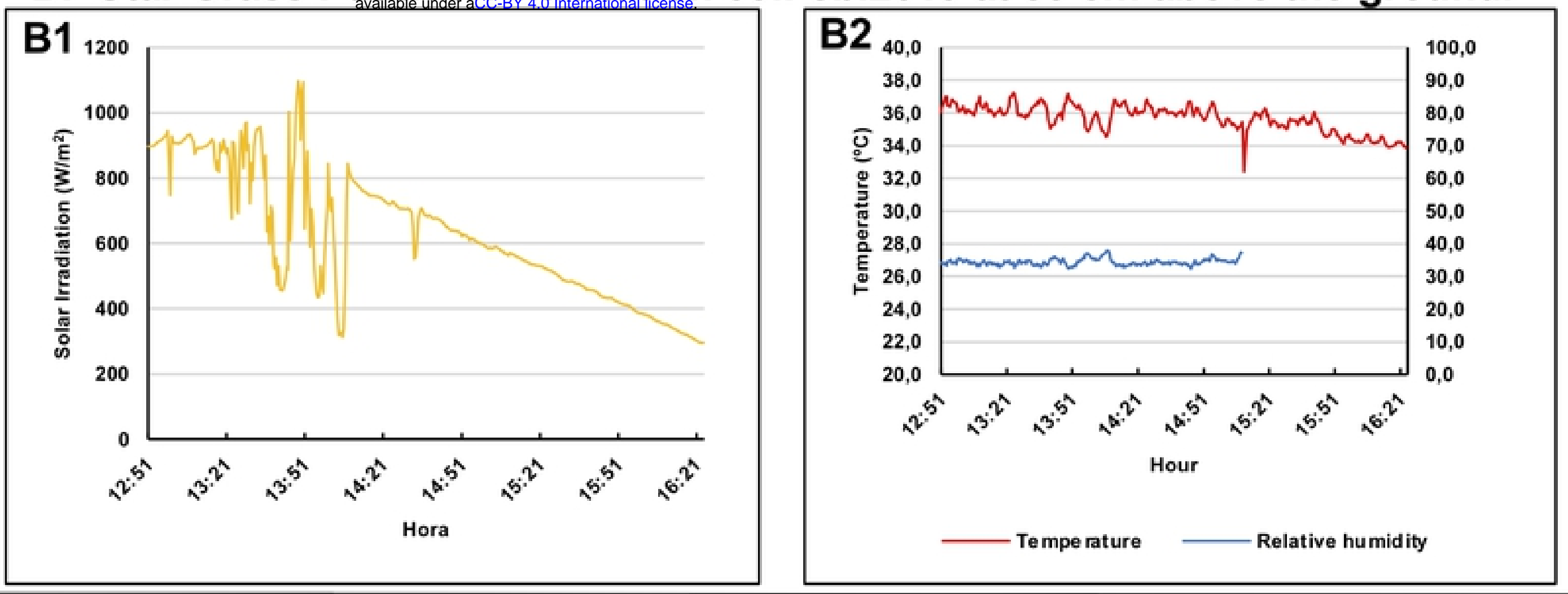

\section{C. 'Riparian Forest' habitat on 10.Feb.2019 at $30 \mathrm{~cm}$ above the ground.}
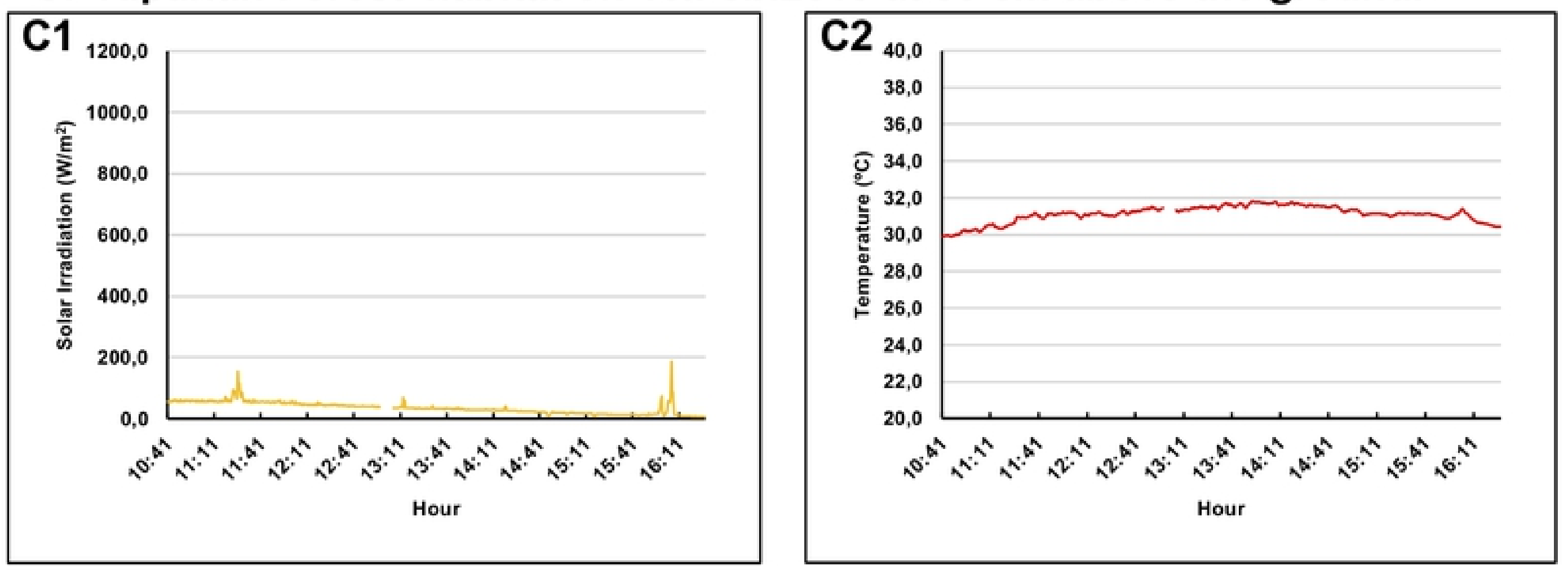

Figure 5 
A. 'Cocoa Crop' habitat on 16.Aug.2019 at $30 \mathrm{~cm}$ above the ground.
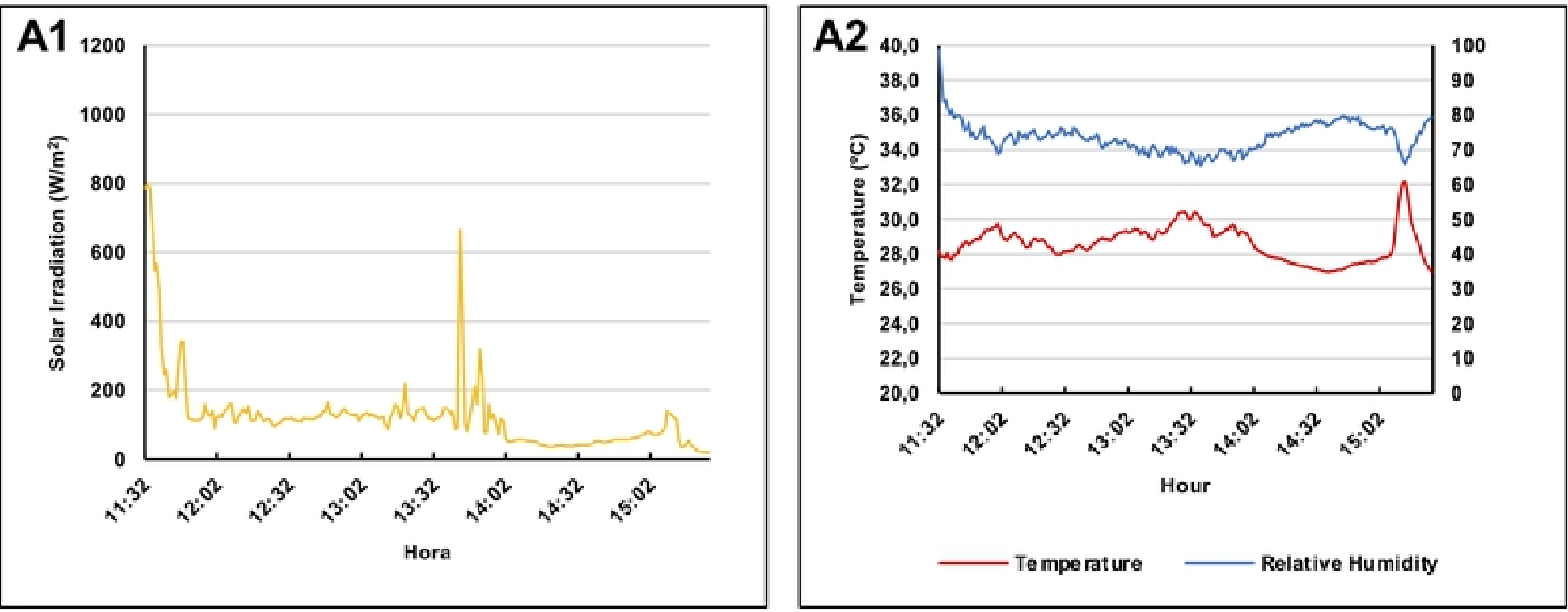

bioRxiv preprint doi: https://doi.org/10.1101/2020.12.23.424125; this version posted December 23, 2020. The copyright holder for this preprint

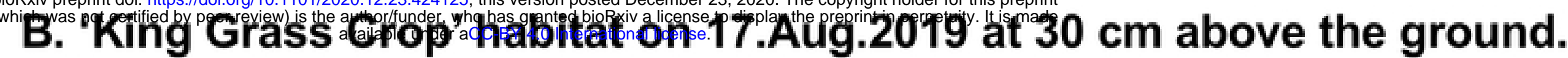
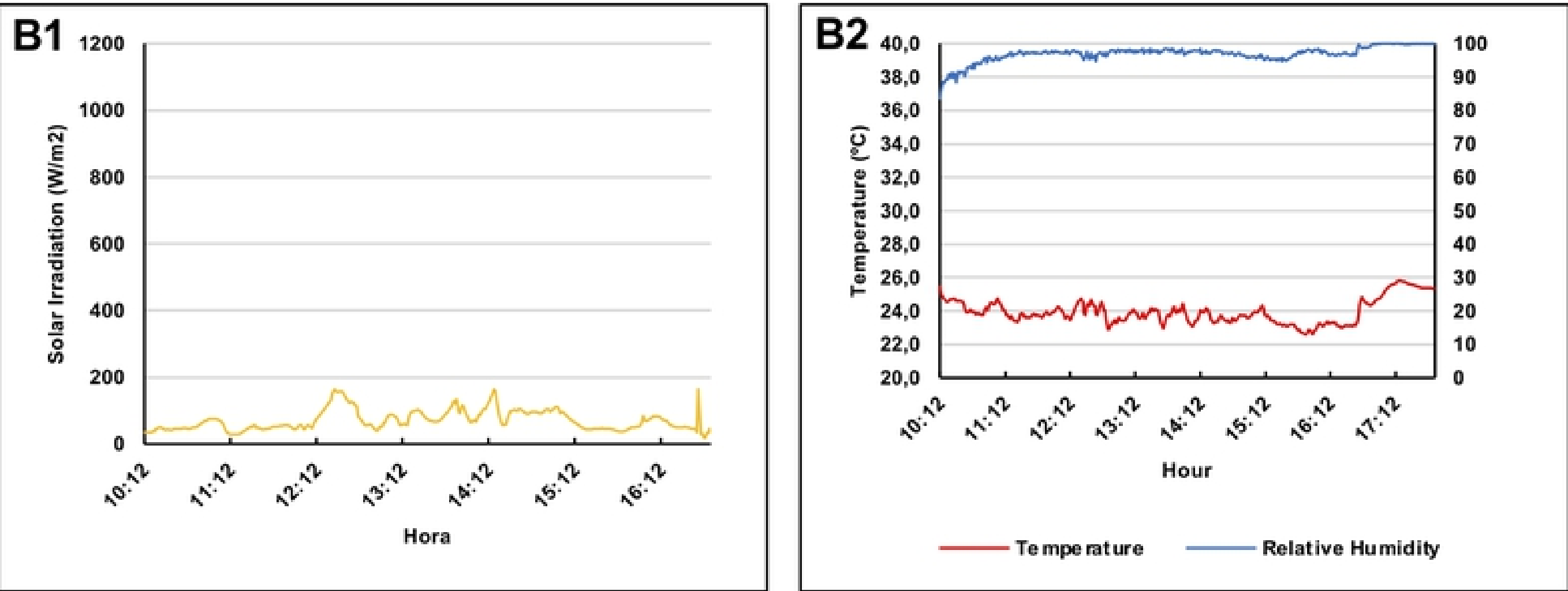

C. Litter at the 'Cocoa Crop' habitat on 16.Aug.2019 at $4 \mathrm{~cm}$ deep inside the
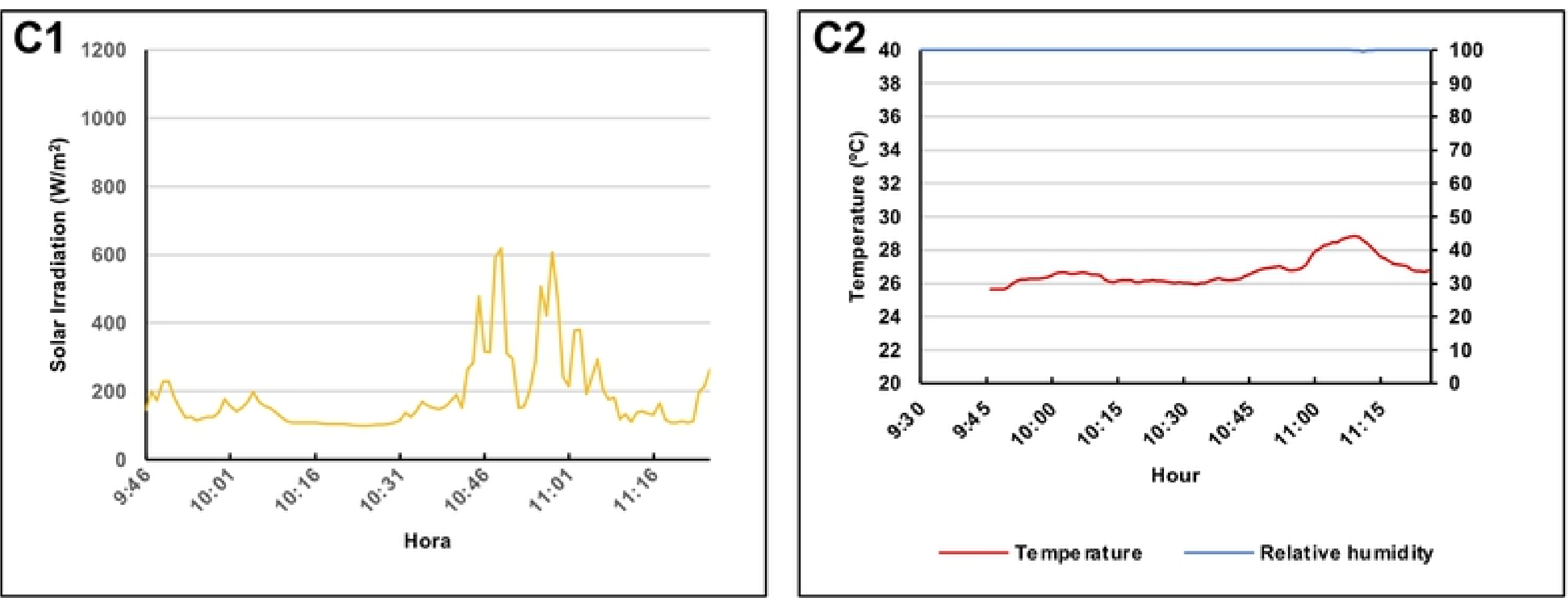

Figure 6 


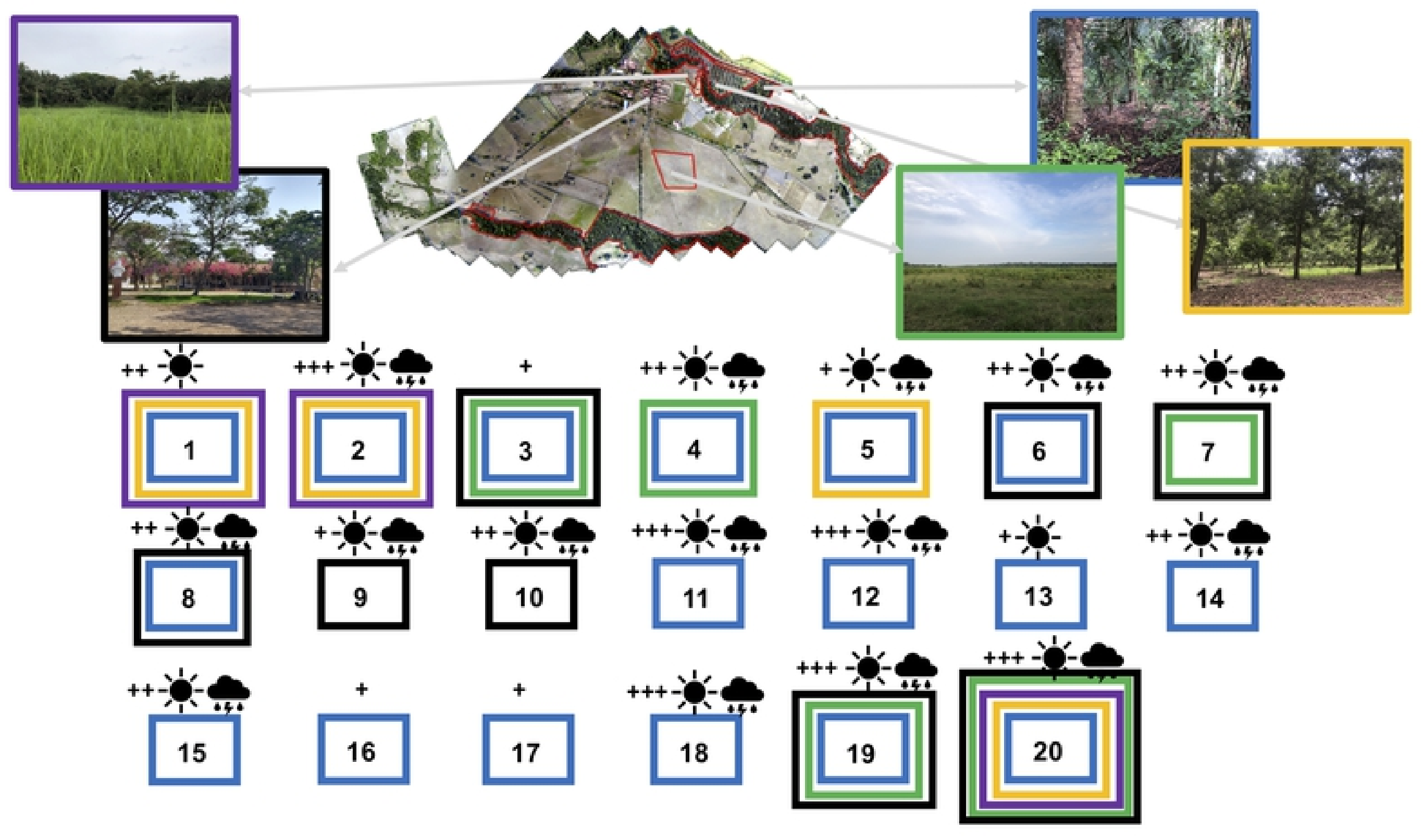

Figure 7 